Geology and Stratigraphy of the East and West Firing Areas Lawrence Livermore National Laboratory Site $\mathbf{3 0 0}$

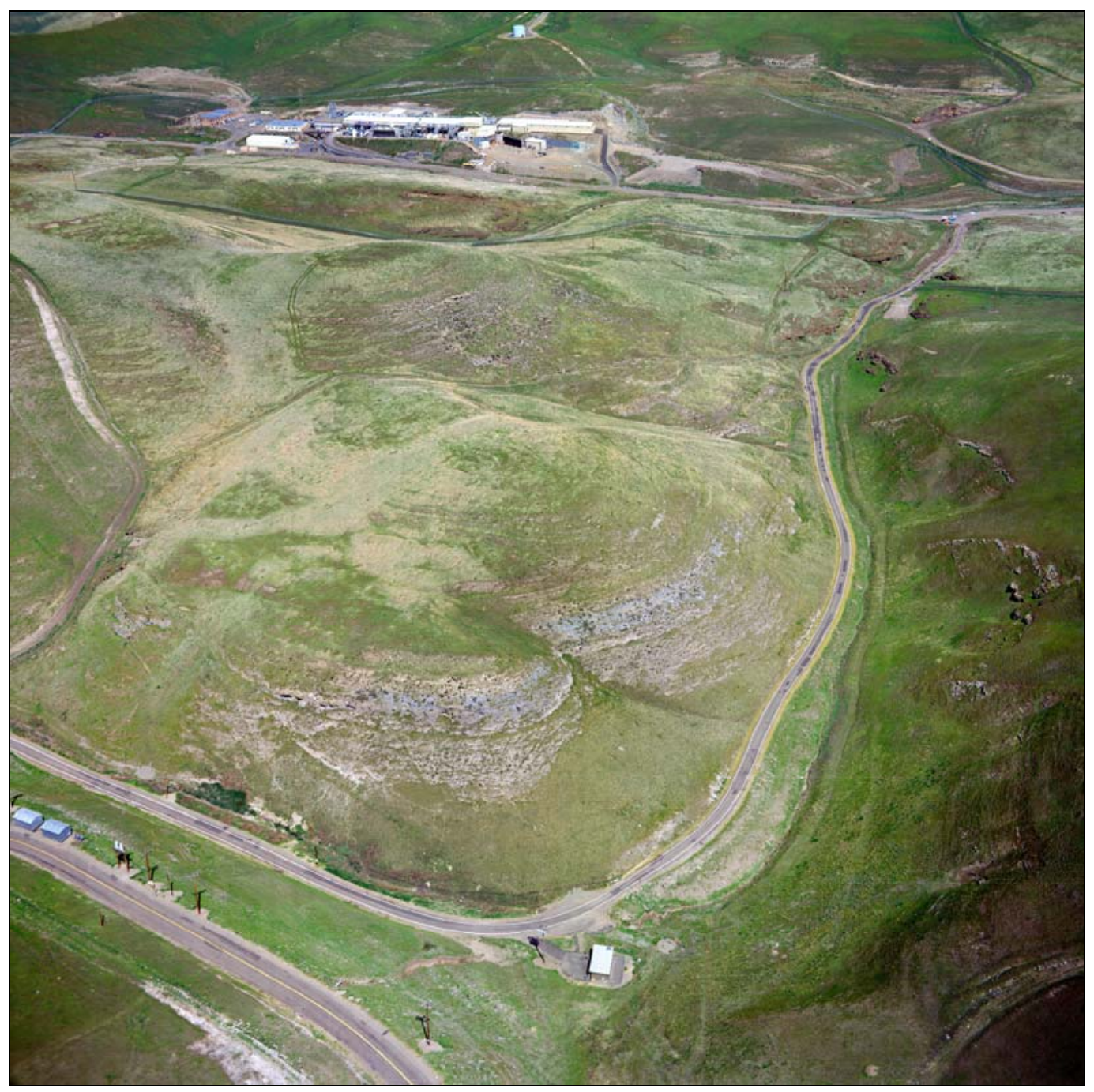

Kenneth D. Ehman, Ph. D., P.G. 6383

May 2006

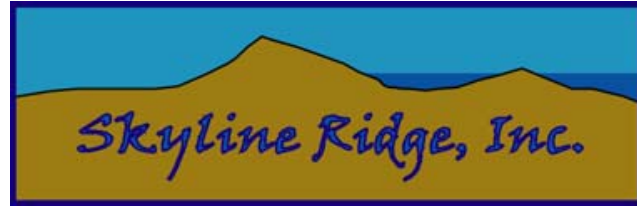

P. O. Box 150

Los Gatos, California 95031-0150

Submitted to fulfill subcontract B539658 
This document was prepared as an account of work sponsored by an agency of the United States Government. Neither the United States Government nor the University of California nor any of their employees, makes any warranty, express or implied, or assumes any legal liability or responsibility for the accuracy, completeness, or usefulness of any information, apparatus, product, or process disclosed, or represents that its use would not infringe privately owned rights. Reference herein to any specific commercial product, process, or service by trade name, trademark, manufacturer, or otherwise, does not necessarily constitute or imply its endorsement, recommendation, or favoring by the United States Government or the University of California. The views and opinions of authors expressed herein do not necessarily state or reflect those of the United States Government or the University of California, and shall not be used for advertising or product endorsement purposes.

This work was performed under the auspices of the U.S. Department of Energy by University of California, Lawrence Livermore National Laboratory under Contract W-7405-Eng-48.

Cover Picture: Oblique aerial photo looking northeast at the Building 865 Complex from 1987, prior to modification of Doall Road. Doall Ravine is in the foreground. Blue-gray sandstones of the Neroly Formation crop out north of Doall Road. Brown outcrops near the intersection of Doall Road are exposures of the lower conglomerate of the Neroly Formation (Tnbs ${ }_{1}$-cong). The Elk Ravine Fault system extends along Elk Ravine, sub-parallel to Route 3. 


\section{Geology and Stratigraphy of the East and West Firing Areas Lawrence Livermore National Laboratory Site 300}

\section{Table of Contents}

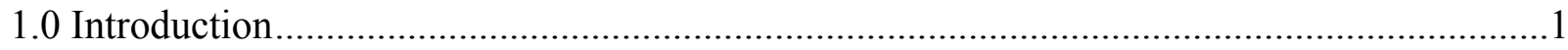

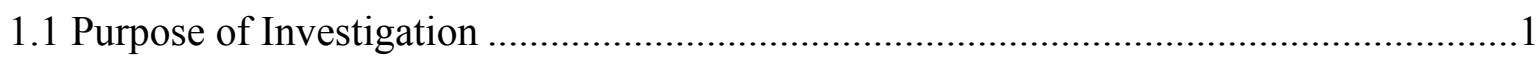

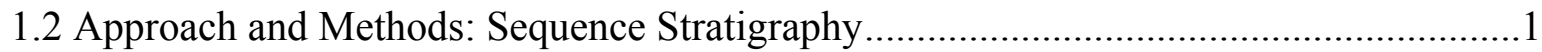

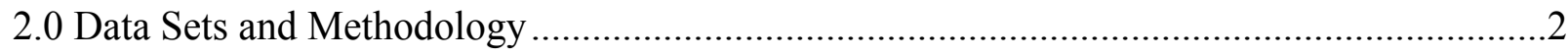

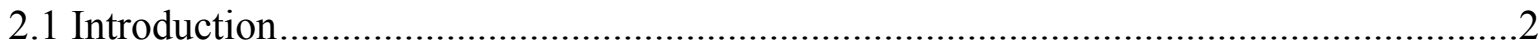

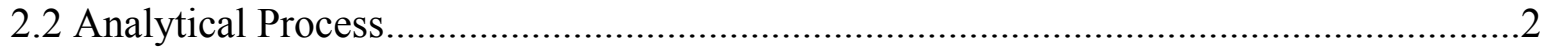

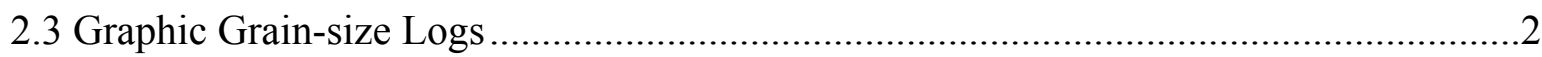

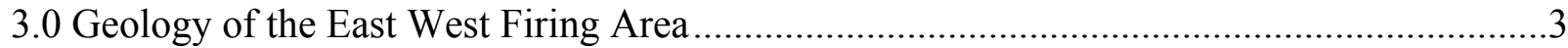

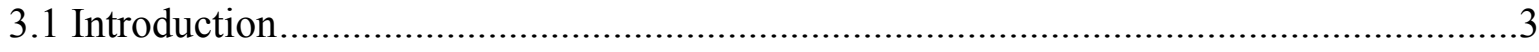

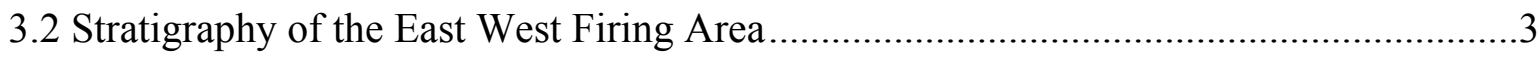

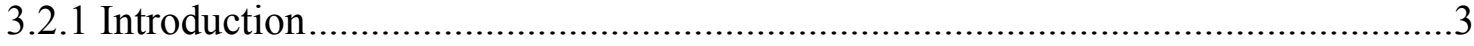

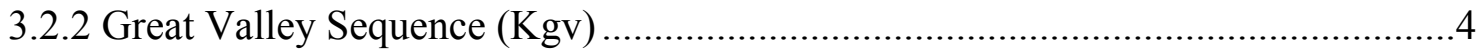

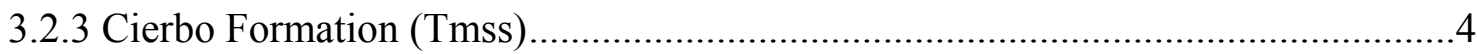

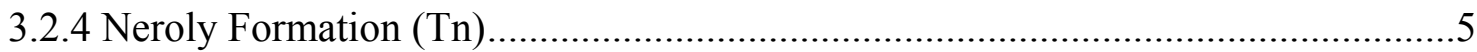

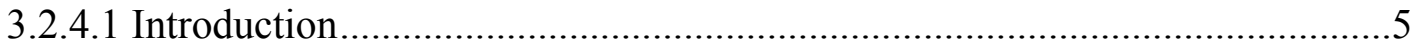

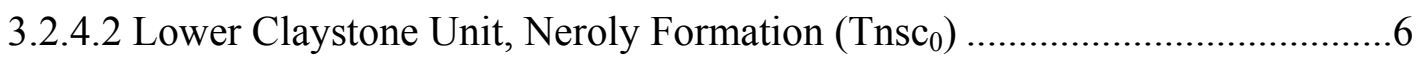

3.2.4.3 Lower Blue Sandstone Unit, Neroly Formation $\left(\mathrm{Tnbs}_{0}\right)$...............................6

3.2.4.4 Lower Conglomerate Unit, Neroly Formation (Tnbs 1 -cong) ..........................6

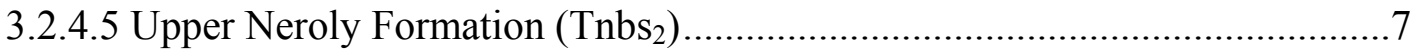

3.2.5 Quaternary Alluvium ....................................................................................

3.3 Structural Geology of the East and West Firing Areas..................................................

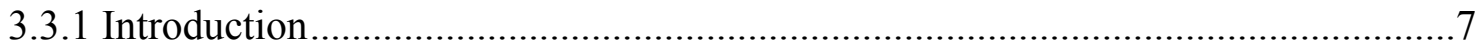

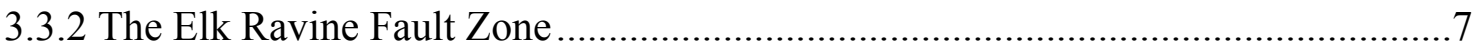

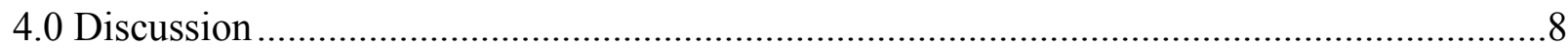

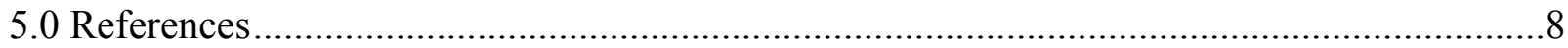

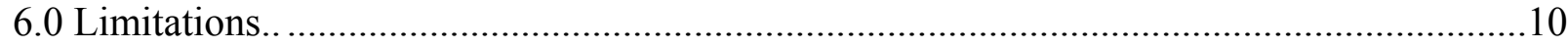

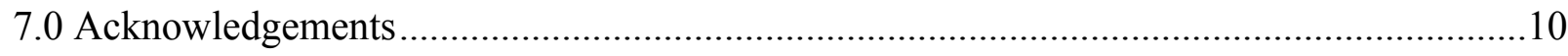

\section{List of Figures}

Figure 1 Location Map of Lawrence Livermore National Laboratory Site 300.

Figure 2 Graphic grain-size log from W-812-01 with explanation of lithology and sedimentary structures.

Figure 3 Conceptual Stratigraphic Model for the East and West Firing Areas 
Figure 4 Portion of geologic map of Section 16 from Carpenter and others (1990)

\section{List of Plates}

Plate 1 Cross section base map of the East West Firing Area

Plate 2 Geologic Cross section A-A'

Plate 3 Geologic Cross section B-B'

Plate 4 Geologic Cross section C-C'

Plate 5 Geologic Cross section D-D'

Plate 6 Geologic Cross section E-E'

Plate 7 Geologic Cross section F-F'

Plate 8 Geologic Cross section G-G'

Plate 9 Geologic Cross section H-H'

Plate 10 Geologic Cross section I-I'

Plate 11 Datumed Stratigraphic Chart - Top Tnbs 0

\section{Appendix}

Appendix A Stratigraphic tops database, East and West Firing Areas 


\subsection{Introduction}

\subsection{Purpose}

The purpose of this project is to gain a better understanding of the stratigraphy and geologic structure of the East and West Firing Areas, at Lawrence Livermore National Laboratory Site 300 (Figure 1). This analysis is designed to help better delineate hydrostratigraphic units (HSUs) in order to enhance the understanding of the fate and transport of contaminants in the subsurface. Specific objectives of the investigation include:

- Evaluation of the stratigraphic relationships between the units that contain tritium in ground water that originates from Pit 7 and the Building 850 area in the vicinity of Doall Ravine;

- The correlation of these units across the Elk Ravine Fault Zone;

- The correlation of these units between the Building 865, Pit 1, Pit 2, and Building 812 areas.

These issues were raised by regulators at the Regional Water Quality Control Board in the review of the Pit $7 \mathrm{RI} / \mathrm{FS}$ (Taffet and others, 2005). The results of this investigation will assist Lawrence Livermore National Laboratory (LLNL) hydrogeologists to conduct work in a more focused and cost-effective manner. This document is submitted to fulfill contract obligations for subcontract B539658.

\subsection{Approach and Methods: Sequence Stratigraphy}

Sequence stratigraphy is a method of describing the aquifers and aquitards in the subsurface that relates the depositional environment of the sediments to the stratigraphic framework in which they were deposited. Sequence stratigraphy provides a tool for predicting the lateral and vertical migration pathways of contaminants in the subsurface.

Sequence stratigraphy is the study of genetically-related sedimentary facies within a framework of chronostratigraphically significant surfaces. A sequence is a relatively conformable, genetically related succession of strata bounded by unconformities. A sequence includes all genetically-related lithologies (facies) between the defining unconformities (sequence boundaries) and may include regionally extensive aquifer and aquitard lithologies. A sequence boundary is a chronostratigraphic surface that can be correlated over a wide area. The identification of sequence boundaries is critical in defining the aquifer architecture of a basin.

A detailed discussion of the criteria for the recognition and correlation of sequence boundaries is found in Van Wagner and others (1990). In the analysis done for the East and West Firing Areas, the focus was the physical stratigraphic correlation between the different boreholes and their ties to surface outcrops. 


\subsection{Data Sets and Methodology}

\subsection{Introduction}

A variety of data sets have been integrated to build the geologic model in the East and West Firing Areas. Sequence stratigraphy provides a means to integrate these data sets into a conceptual geologic model. Data sets available include:

- Lithologic descriptions from boreholes.

- Preserved continuous core.

- Geophysical log suites from boreholes.

- Optical televiewer logs (OPTV logs) from boreholes.

- Geologic mapping.

- High-resolution aerial photography.

- Photographic panoramas of the East and West Firing Areas.

\subsection{Analytical Process}

The process of the investigation has been:

- The review and compilation of well files.

- Construction of graphic grain-size logs from core descriptions

- Examination of core from several key wells: W-812-2009; W-896-1806, W865-05, W-PIT7-14, W-PIT7-16, W-PIT7-1925, NC7-74

- Examination of outcrop geology in the East and West Firing Areas

- Review of geologic section maps from Sections 16, 21 and 22 (see Section 3.1) (Carpenter and others, 1990)

- Construction of datumed stratigraphic and structural cross sections integrating graphic grain-size logs, borehole geophysical logs, core descriptions, and outcrop geology.

\subsection{Graphic Grain-size Logs}

Plate 1 presents the location of the 9 geologic cross sections constructed as part of this investigation. Graphic grain-size logs were constructed for the wells in the East and West Firing Areas. Figure 2 is an example from W-812-01 with an explanation of lithology and sedimentary structures. Figure 3 is a conceptual stratigraphic model utilizing some of the cores that have been examined over the last several years.

Geophysical logs, if available, are plotted on either side of the lithologic column. The gamma ray log is plotted on the left side of the lithology column, and the resistivity log is plotted on the right. Well construction details (sand pack and screened intervals) are shown on the left side of the lithologic column (Figure 2 and 3).

Cross sections (Plates 2 - 10) were initially constructed using the EarthVision cross section tool. These cross sections were exported as post script files and modified in Adobe Illustrator. Each 
cross section shows a 5 to 1 vertically exaggerated section with the graphic grain-size logs above a one to one (no exaggeration) section with just the location of the wells or boreholes.

\subsection{Geology of the East and West Firing Areas}

\subsection{Introduction}

The surface geology of the East and West Firing Areas was mapped by Carpenter and others (1990) at a scale of 1.0 inch $=200$ feet and presented as a series of section maps of T3N, R4W. These section geologic maps were compiled and presented in Webster-Scholten (1994). Portions of the geologic maps from Sections 16, 21, and 22 were used in this investigation. An example of a portion of the geologic map from Section 16 is presented on Figure 4.

\subsubsection{Introduction}

The conceptual stratigraphic model for the East and West Firing Areas is presented on Figure 3. Five formations underlie the East and West Firing Areas, the Great Valley Sequence (Cretaceous), the Cierbo Formation (Miocene), the Neroly Formation (Miocene), Pliocene Sediments, and alluvium (Recent). Landslide deposits are also present in the East and West Firing Areas, but were not addressed as part of this investigation.

Eight sequence boundaries divide the stratigraphy into a series of sequence stratigraphic rock units and are shown on the geologic cross sections A-A', B-B', C-C', D-D', E-E', F-F', G-G', HH', I-I' (Plates $2-10$ ), and datumed the stratigraphic chart (Plate 11). The datum used on Plate 11 is the top of the $\operatorname{Tnbs}_{0}$. These seven sequence boundaries are:

- Top of the Great Valley Sequence (Top of Kgv). This is a major angular unconformity separating the Cretaceous-aged Great Valley Sequence from the overlying Miocene-aged Cierbo Formation (Tmss).

- Middle Cierbo sequence boundary. This surface separates the middle member of the Cierbo Formation (Tmss-middle) from the lower member of the Cierbo Formation (Tmss-lower).

- Base Neroly sequence boundary. This surface separates the fine-grained upper Cierbo Formation (Tmss-upper) from the dominantly fine-grained lower member of the Neroly Formation $\left(\operatorname{Tnsc}_{0}\right)$.

- Base $\operatorname{Tnbs}_{0}$ sequence boundary. This surface separates the lowermost, major bluecolored sandstone of the Neroly Formation $\left(\mathrm{Tnbs}_{0}\right)$ from the lower fine-grained member of the Neroly Formation $\left(\mathrm{Tnsc}_{0}\right)$.

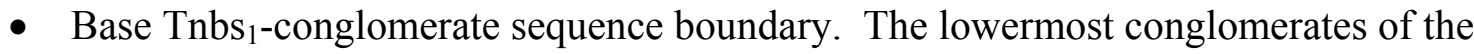
Neroly Formation ( Tnbs $_{1}$-cong) rest on this surface.

- Base $\operatorname{Tnbs}_{2}$ sequence boundary. The uppermost conglomerates and coarse-grained sandstones of the Neroly Formation $\left(\mathrm{Tnbs}_{2}\right)$ rest on this surface. This surface has been correlated from the Building 832 Canyon area, and is equivocal. The results of this investigation suggest that the $\operatorname{Tnbs}_{2}$ mapped on the ridge northeast of the Pits 3,5 and 7 area does not correlate to the Tnbs $_{2}$ mapped to the east of the Building 865 area. This is discussed in Section 3.2.5.2. 
- Base Pliocene sequence boundary. This surface separates the Pliocene sediments (Tps) from the underlying Miocene Neroly Formation.

- Base of alluvium sequence boundary. This surface separates Recent-aged alluvium found in the present-day valleys and ravines of Site 300 from the underlying Pliocene, Miocene, and Cretaceous Formations.

In addition to the eight sequence boundaries, two other surfaces are correlated on the geologic cross sections (Figure 3, Plates 2-11):

- Top of the Cierbo Formation lithostratigraphic surface. Historically, this surface has been mapped as the top of the Cierbo Formation, and is the top of the first significant quartz-rich sandstone within the Cierbo Formation.

- Top of the $\operatorname{Tnbs}_{0}$. This surface is the top of the $\mathrm{Tnbs}_{0}$ sandstone, and is a flooding surface that can be widely correlated. Figure 3, the conceptual stratigraphic framework, is datumed on this surface. In addition, Plate 11 is a stratigraphic correlation chart that is datumed on this surface.

Other correlation surfaces, shown as solid and dashed black lines, are shown on the cross sections. Solid black lines represent bases of sandstone (and conglomerate) channels while dashed lines represent the overlying flooding surfaces.

Appendix A presents the depths/elevations of the surfaces for the wells/boreholes utilized in this investigation.

The Pliocene sediments (Tps) are only observed in four boreholes in the study area and are not saturated and were not studied in detail.

\subsubsection{The Great Valley Sequence (Kgv)}

The Great Valley Sequence is the oldest rock unit exposed at Site 300, and has been mapped along the northern boundary of the area (Webster-Scholten, 1994). The unit appears to be present in six wells/boreholes used in this investigation: K1-01, K2-04, K7-03, NC7-50, W-8651804 (equivocal), and W-896-1806. The most complete description of the Great Valley Sequence comes from W-896-1806 (Figure 3, Plates 2 and 7). In W-896-1806, the Great Valley Sequence is present from 289 feet bgs to TD at 352 feet bgs and is a dominated by dark gray, thinly laminated shale with thin, convolutedly laminated, graded fine sandstones and siltstones. Beds dip at $35^{\circ}$ to $45^{\circ}$ compared to the relatively low-dipping Cierbo Formation which rests above the Great Valley Sequence. Exposures of the Great Valley Sequence at Site 300 were mapped with a strike of approximately north $15^{\circ}$ east and dip of approximately $52^{\circ}$ (WebsterScholten, 1994).

\subsubsection{Cierbo Formation (Tmss)}

In the East and West Firing Areas, the Cierbo Formation (Tmss) is informally divided into three members, lower, middle and upper. The unit is distinguished by the presence of light gray friable quartzose sandstones, as opposed to the blue-gray volcanic-rich sandstones of the overlying Neroly Formation. The Miocene Cierbo Formation rests above the Cretaceous Great 
Valley Formation along an angular unconformity. This contact is poorly exposed at Site 300 but is present in several boreholes, including W-896-1806 (Figure 3).

Ehman (2005) defined the upper contact of the Cierbo Formation in the Building 812 area (Figure 3). In previous Site 300 geologic reports, the top of the Cierbo Formation has been recognized by the first occurrence of quartzose sandstone in contrast with the overlying volcanic-clastic Neroly sandstones. The quartzose sandstones of the Cierbo Formation appear to be channelized and discontinuous, thus the contact between the formations is not a continuous correlative surface that can be easily mapped. Webster-Scholten (1994) showed the mapped contact at the base of the Tnbs0, but later work by other Site 300 hydrogeologists demonstrated the presence of the Tnsc0 beneath the Tnbs0.

The sandstone within the Cierbo Formation is characterized by fine- to medium-grained, light gray to light olive gray sandstone that is finely laminated, and shows both cross beds and ripple laminations. Some of the laminations are thin organic-rich layers (coaly material). In core from W-812-2009, and W-896-1806, W-PIT7-1925, some of the sandstone appears to be burrowed and bioturbated and no laminations are present. Rock fragments and feldspar grains are also present in the sandstones. Because the sand is very friable, recovery tends to be fair to poor through the interval.

Finer-grained lithologies are observed within the Cierbo Formation where quartzose sandstone is interbedded with dark greenish-gray clayey siltstone, silty claystone, sandy siltstone, and silty sandstone. The clayey siltstone and silty claystone are fractured and typically have a sheared appearance in core, and is difficult to distinguish from similar lithologies in $\operatorname{Tnsc}_{0}$.

The lower member of the Cierbo Formation is observed in W-896-1806 between 230 and 289 feet bgs, but has not been described in detail in other boreholes.

\subsubsection{Neroly Formation (Tn)}

\subsubsection{Introduction}

The Neroly Formation (Tn) is divided into five informal members in the East West Firing Area:

- The lower claystone unit, Tnsc $_{0}$

- The lower sandy member, Tnbs $_{0}$

- The main coarse-grained member, Tnbs $_{1}$

- The middle fine-grained member, Tnsc $_{1}$

- The upper coarse-grained member, $\mathrm{Tnbs}_{2}$

The main water-bearing units include the Tnbs0 and the Tnbs 1 and were the focus of this investigation. The Tnbs 0 is shown in yellow on Figure 3 and on Plates $2-11$. The conglomerate unit within the Tnbs1 (Tnbs1-cong) is shown in orange on Figure 3 and on Plates 2 -11 . 


\subsubsection{Lower Claystone Unit, Neroly Formation $\left(\operatorname{Tnsc}_{0}\right)$}

The lower claystone unit in the Neroly Formation ( $\mathrm{Tnsc} 0$ ) rests unconformably above mudstones and sandstones of the upper Cierbo Formation (Figure 3; Plate 11) and below the sandstones and silty sandstones of the Tnbs0. The unit is dominated by dark greenish-gray claystone, siltstone, clayey siltstone and silty claystone with thin, discontinuous silty sandstones and sandy siltstones. The bedding features within the finer-grained lithologies are homogenized by rooting and show some evidence of bioturbation. The clayey siltstones and silty claystones are fractured and typically have a sheared appearance in core.

In the Building 812 Area, the contact between the Neroly and Cierbo Formation is subtle, and was recognized after detailed examination of core from W812-1924 and W-812-2009 (Ehman, 2005). Ehman (2005) suggested there appeared to be a discrete, slightly discordant unconformity between the Cierbo and overlying Neroly Formations. Cross section A-A' (Plate 2) shows evidence of this discordance by showing Tnsc0 thinning to from a thickness of approximately 145 feet in the Building 812 area, to approximately 60 feet in the Building 865 area (see Figure 3; Plates 2 and 11). This could either be caused by onlap of Tnsc 0 on the basal Neroly contact, or possibly caused by structural thickening in the Building 812 area caused by an undetected thrust or reverse fault cutting W-812-2009.

Carpenter and others (1990) considered the upper contact of the Cierbo Formation to be the base of the Tnbs 1 and did not recognize the fine-grained $\operatorname{Tnsc}_{0}$ as part of the Neroly Formation.

\subsubsection{Lower Blue Sandstone Unit, Neroly Formation $\left(\mathrm{Tnbs}_{0}\right)$}

The lower blue sandstone unit in the Neroly Formation $\left(\mathrm{Tnbs}_{0}\right)$ rests unconformably above mudstones, siltstones, and sandstones of the $\mathrm{Tnsc}_{0}$ and unconformably below the conglomerate of the Tnbs 1 -cong (Figure 3; Plate 11).

Ehman (2005) divided the $\mathrm{Tnbs}_{0}$ into three subunits in the Building 812 area $\left(\operatorname{Tnbs}_{0}-\mathrm{A}, \mathrm{Tnbs}_{0}-\mathrm{B}\right.$, and $\operatorname{Tnbs}_{0}-\mathrm{C}$ ). Thin siltstones and claystones separate the three subunits. To the north in the East and West Firing Areas, only the lowermost unit, the $\mathrm{Tnbs}_{0}-\mathrm{C}$, was correlated throughout the study area, and is here defined specifically as the $\mathrm{Tnbs}_{0}$ with a sequence boundary at the base and capped by a flooding surface (shown as a dotted green line on Figure 3 and all the plates). $\mathrm{Tnbs}_{0}$ rests unconformably on the $\mathrm{Tnsc}_{0}$ and is a dark grayish brown to dark bluish gray fine- to medium- sandstone that is parallel laminated and is generally between 10 to 20 feet thick. The $\mathrm{Tnbs}_{0}$ is one of the main water-bearing units in the study area.

\subsubsection{Lower Conglomerate Unit, Neroly Formation, (Tnbs 1 -cong)}

The lower conglomerate unit of the Neroly Formation (Tnbs ${ }_{1}$-cong) is well-exposed in the Building 812 Area on both sides of the Building 812 Canyon Fault (Ehman, 2005). In the East and West Firing Areas, the unit is exposed on the eastern end of Doall Ravine. The Tnbs 1 -cong rests along a sharp, erosive contact above the sandstones and siltstones that have been mapped as both $\mathrm{Tnbs}_{0}$ and $\mathrm{Tnbs}_{1}$ (Figure 3, Plates 2 - 11). The unit is composed of pebble- to cobble- clast supported conglomerate with interstratified sandstone and gravelly sandstone. Clasts are dominantly volcanic in origin. The thickness of this unit is variable, but is locally up to 50 feet thick. The conglomerate is overlain by fining upward channel fill packages of gravelly 
sandstone, sandstone, siltstone and claystone of the $\operatorname{Tnbs}_{1}$. The overlying $\mathrm{Tnsc}_{1}$ is not well defined in the East and West Firing Areas and thus was not correlated as part of this investigation. Further work is needed to correlate the southern area of Site 300 with the East and West Firing Areas.

\subsubsection{Upper Neroly Formation $\left(\operatorname{Tnbs}_{2}\right)$}

The upper Neroly Formation is only observed in a few wells/boreholes in the East and West Firing Areas, since the unit is restricted to the upper portions of some of the higher hills in the region. It is not clear how the Tnbs 2 that is so well defined in the southern part of Site 300 correlates to the East and West Firing Areas. Analysis of the geologic map presented in Webster-Scholten (1994) indicates that the $\mathrm{Tnbs}_{2}$ mapped on the northeastern side of the Elk Ravine Fault (observed in wells W-865-05, W-865-2005, and W-865-2121) does not correlate with the Tnbs 2 mapped on the south side of the Elk Ravine Fault (observed in borehole NC7-74).

The $\mathrm{Tnbs}_{2}$ consists of gravelly sandstones and conglomerate that is overlain by siltstones and claystones of probable $\mathrm{Tnsc}_{2}$ in W-865-2005 and W-865-2121, and the Tps in NC7-74

\subsubsection{Alluvium}

Thin alluvial deposits and weathered bedrock are present in Elk Ravine, the Pit 7 area, and in Doall Ravine. Alluvial materials include sand, silt, silty sand, sandy clay, and gravelly silt and gravelly sand.

\subsection{Structural Geology of the East and West Firing Areas}

\subsubsection{Introduction}

The East and West Firing Area can be divided into three structural domains delineated by the Elk Ravine Fault zone (Plate 1):

- Southwest domain, defined as the region southwest of the Elk Ravine Fault

- Central domain, defined as the region in between the northeastern branch and southwestern branch of the Elk Ravine Fault zone

- Northeast domain, defined as the region northeast of the Elk Ravine Fault

The Elk Ravine Fault zone extends northwest to southeast through the East and West Firing Areas and affects both the bedrock stratigraphy and the modern day topography. Along the northwestern end the fault zone is bifurcated in the area around Building 865 and Pit 2, and merges to become a single fault zone northwest of the Building 812 area.

\subsubsection{Elk Ravine Fault Zone}

The Elk Ravine Fault was first shown on the regional geologic map of Dibblee (1980). Hydrogeologic investigations in the early 1980's confirmed the presence of the fault zone, and these studies suggested that the southwestern branch of the fault was a groundwater barrier (Carpenter and Peifer, 1983). Trenching across the fault north of Pit 1 in 1988 detected the fault offsetting bedrock but not offsetting alluvial material (Hoffman, 1988). 
Dugan (1990) mapped the area around Elk Ravine and Doall Ravine and recognized additional faulting approximately 200 feet west of the Pit 2 . These features were trenched and mapped as thrust/reverse faults (Plate 1). Offset on these features is unclear. Cross sections shown on Plates $2-10$ do not show these features since they do not appear to have significant offset of the stratigraphic units.

Cross sections F-F', G-G', H-H', and I-I' (Plate 7 - 10) cross the two branches of the Elk Ravine Fault zone. All of these sections show the faults as vertical with the exception of $\mathrm{H}-\mathrm{H}^{\prime}$ (Plate 9) that shows the west branch of the Elk Ravine Fault dipping steeply to the east. This dip is based on the interpretation that there is a fault in W-865-1802 that cuts out section. Although Hoffman (1988) observed a fault zone in a trench in Pit 1 (west branch of the Elk Ravine Fault zone) dipping $28^{\circ}$ to the southwest, the surface trace of the fault appears relatively straight, suggesting a steeper dipping fault zone (Plate 1).

The Elk Ravine Fault zone is interpreted to be a right-lateral wrench fault system (Dugan, 1990), and based on borehole data, there is significant dip-slip on both branches of the fault. The western branch appears to be down to the east, while the eastern branch appears to be down to the west (Plates $1-10)$. The central domain between the two branches appears to be a graben, suggesting extensional displacement (normal displacement). However, the documented occurrence of thrust faults on the west side of the fault system suggests contractual displacement along the fault zone. Although most of the displacement of the fault zone appears to have taken place on the two main branches, it is clear that the zone contains numerous unmapped faults with varying degrees of displacement.

\subsection{Discussion}

Nine geologic cross sections aid in delineating both the stratigraphy and structure of the East and West Firing Areas. The definition and delineations of the stratigraphy and structure of the East and West Firing Areas is the first step in the hydrostratigraphic analysis of the groundwater system in the area. Based on this analysis, a stratigraphic tops database has been established (Appendix A). Working with LLNL hydrogeologists, a 3-dimensional EarthVision hydrogeologic model will be generated by integrating the surface and subsurface data.

\subsection{References}

Carpenter, D. W. and Peifer, Eds., (1983) Supplementary Data Report, Site 300, Chemical and Hydrogeological Assessment, Lawrence Livermore National Laboratory, Livermore California, UCID-19801.

Carpenter, D. W., Dugan, W.R., Matiek, R. S. and Taffet, M. J., 1990, Preliminary Geologic Map of Sections 16, 21, and 22 (T3N, R4W), Lawrence Livermore National Laboratory Site 300 (unpublished).

Dugan, W. R., 1994, The Hydrogeology of Doall Ravine and Northern Portions of Elk Ravine, Lawrence Livermore National Laboratory, Site 300, San Jose State University, 44 p. [unpublished M.S. Thesis]. 
Ehman, K. D., 2005, Geology and Stratigraphy of the Building 812 Area, Site 300, Lawrence Livermore National Laboratory, UCRL-SR-213565

Taffet, M. and others, 2005, Final Remedial Investigation/Feasibility Study for the Pit 7 Complex at Lawrence Livermore National Laboratory Site 300, UCRL-AR-202492, July 2005

Van Wagoner, J. C., Mitchum, R. M., Campion, K. M., and Rahmanian, V. D., 1990. Siliciclastic sequence stratigraphy in well logs, cores, and outcrops: American Association of Petroleum Geologists Methods in Exploration Series, No. 7, 55 p.

Webster-Scholten, C. P., (editor), 1994, Site-wide Plates, Final Site-Wide Remedial Investigation Report, Lawrence Livermore National Laboratory, Site 300, UCRL-AR108131 


\subsection{Limitations}

This report and evaluation presented herein have been prepared in accordance with generally accepted professional standard and is based solely on the scope of work and services described herein. This document has been prepared solely for the use of Lawrence Livermore National Laboratory. Any use of this report, in whole or in part, by a third party for other than the purposes noted herein is at such party's sole risk.

\subsection{Acknowledgements}

The author would like to thank Vic Madrid, John Radyk, and Michael Taffet of the Environmental Restoration Division of Lawrence Livermore National Laboratory for their technical contributions and review of this work. Data for this investigation were supplied by Rob Davis, Denise Mason, Pete McKereghan, Will McConihe, John Valett, Sevin Bilir, Mark Buscheck, and Zafer Demir. 


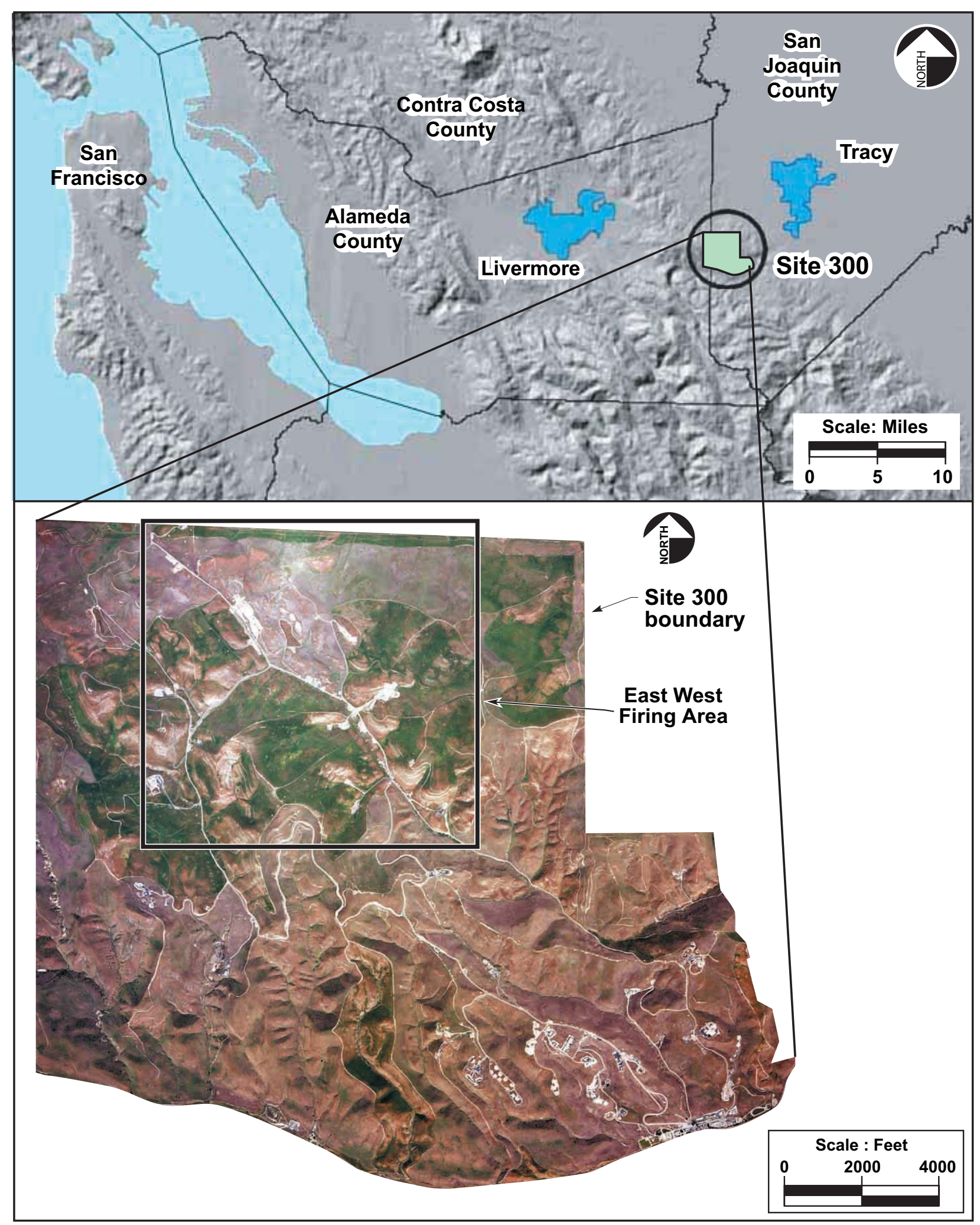

Figure 1. Location Map of Site 300, Lawrence Livermore National Laboratory 


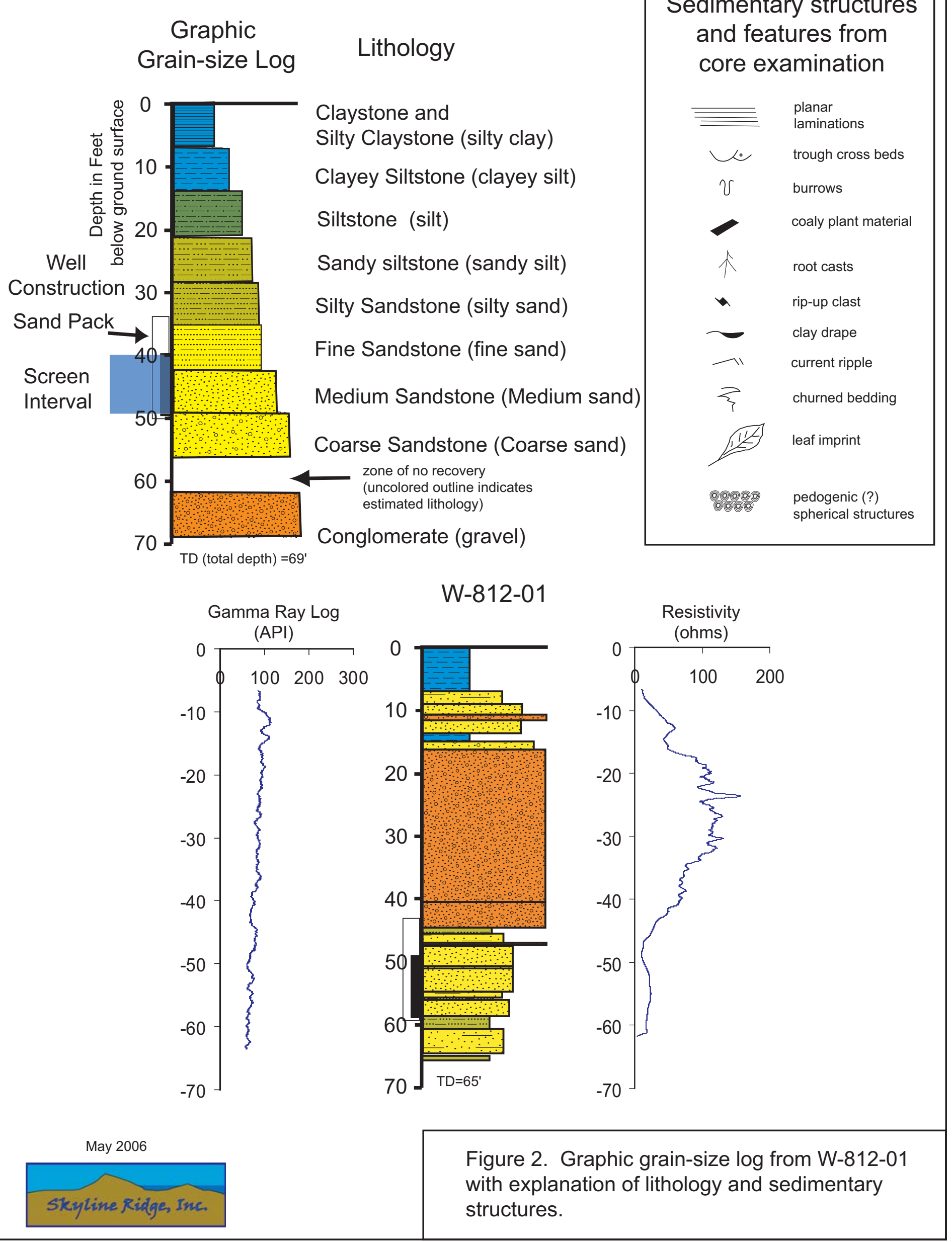




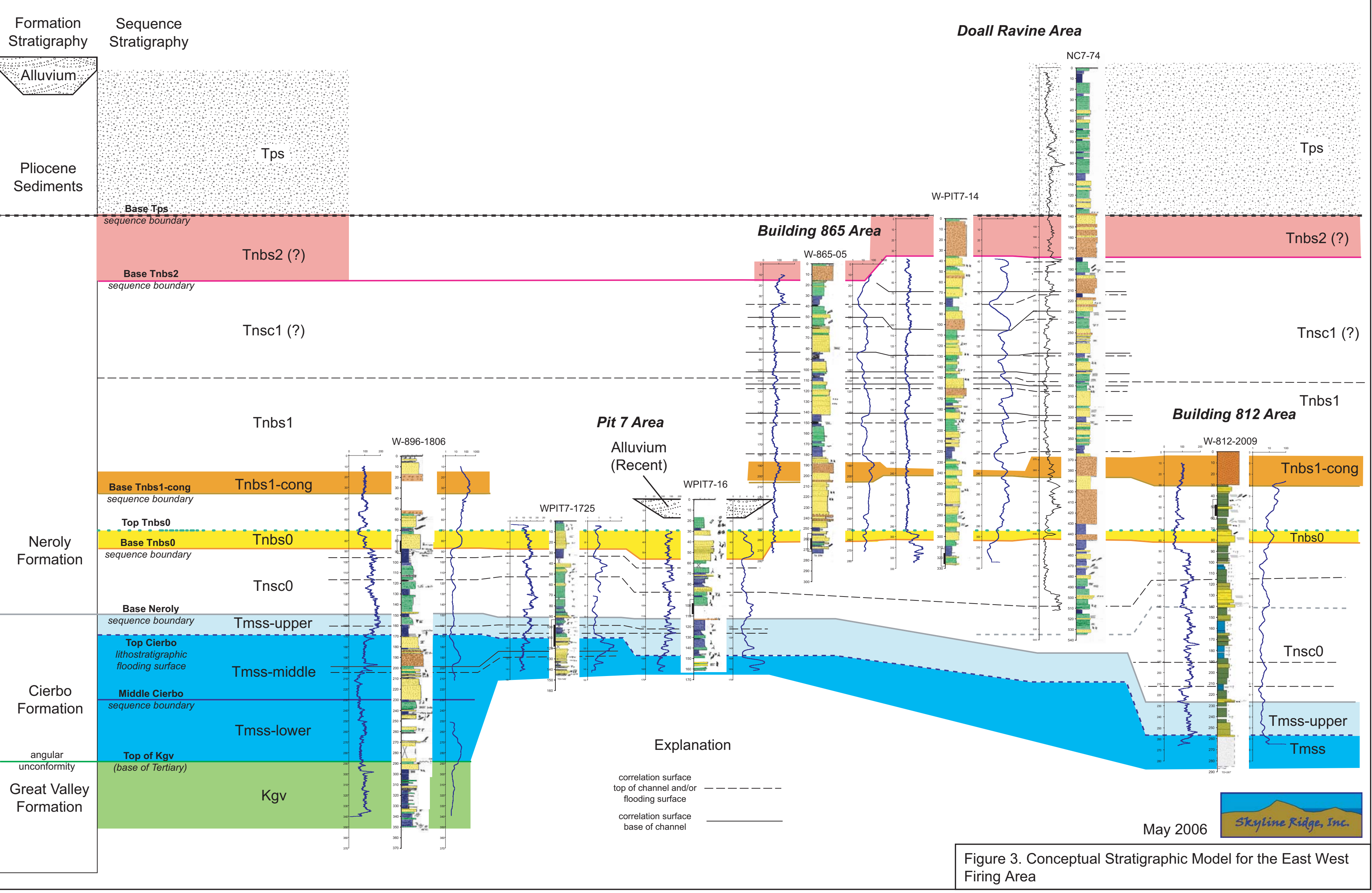




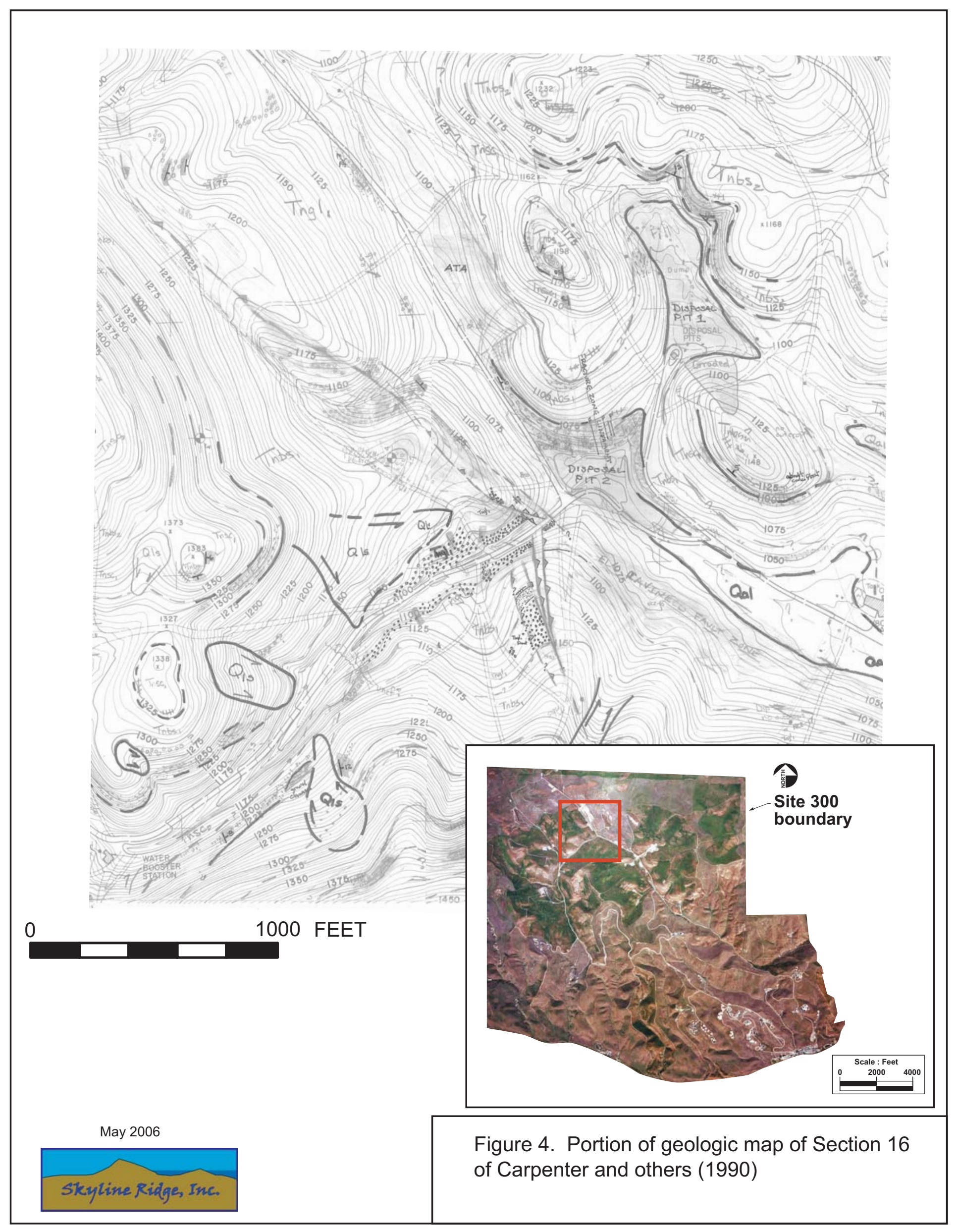




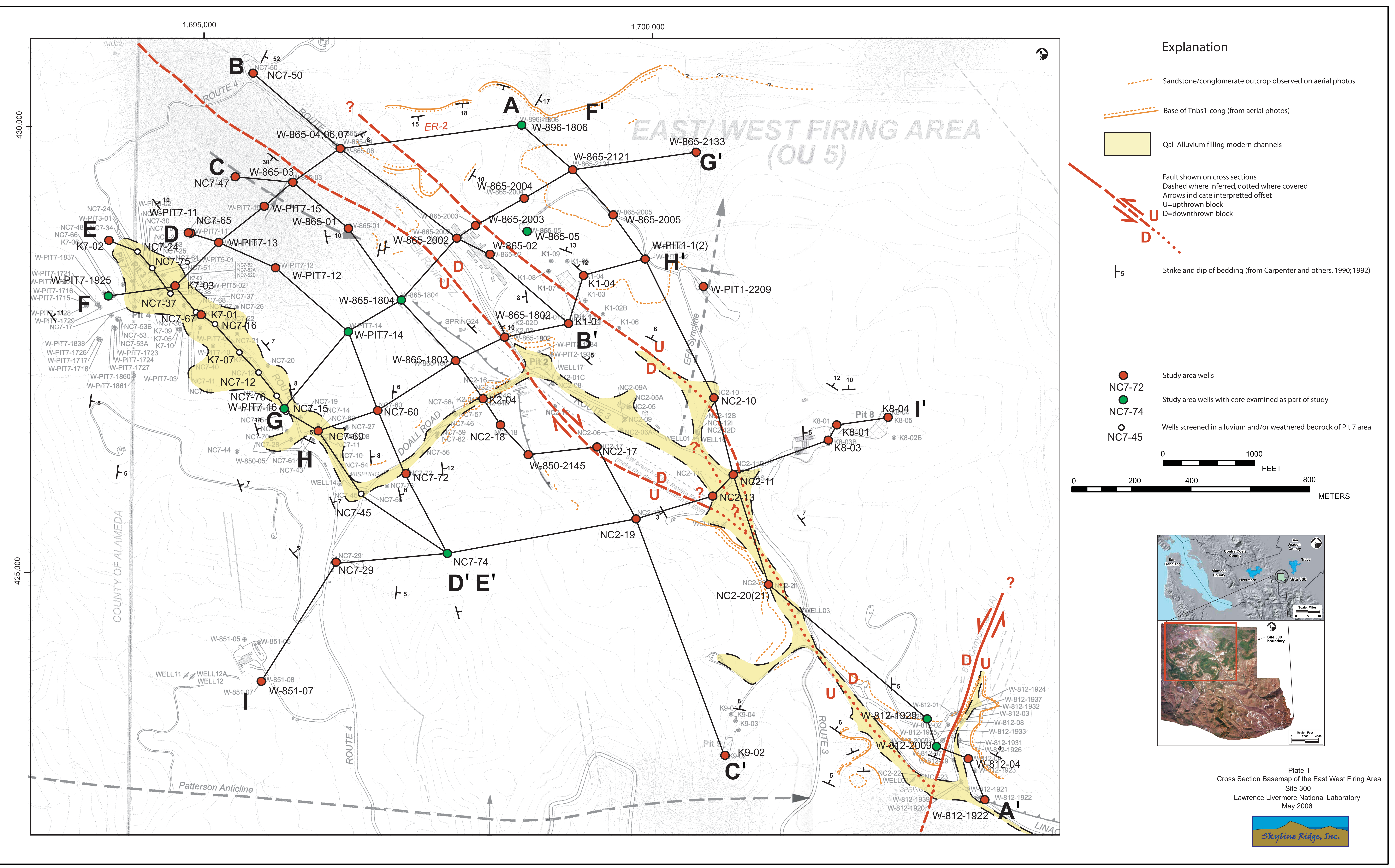





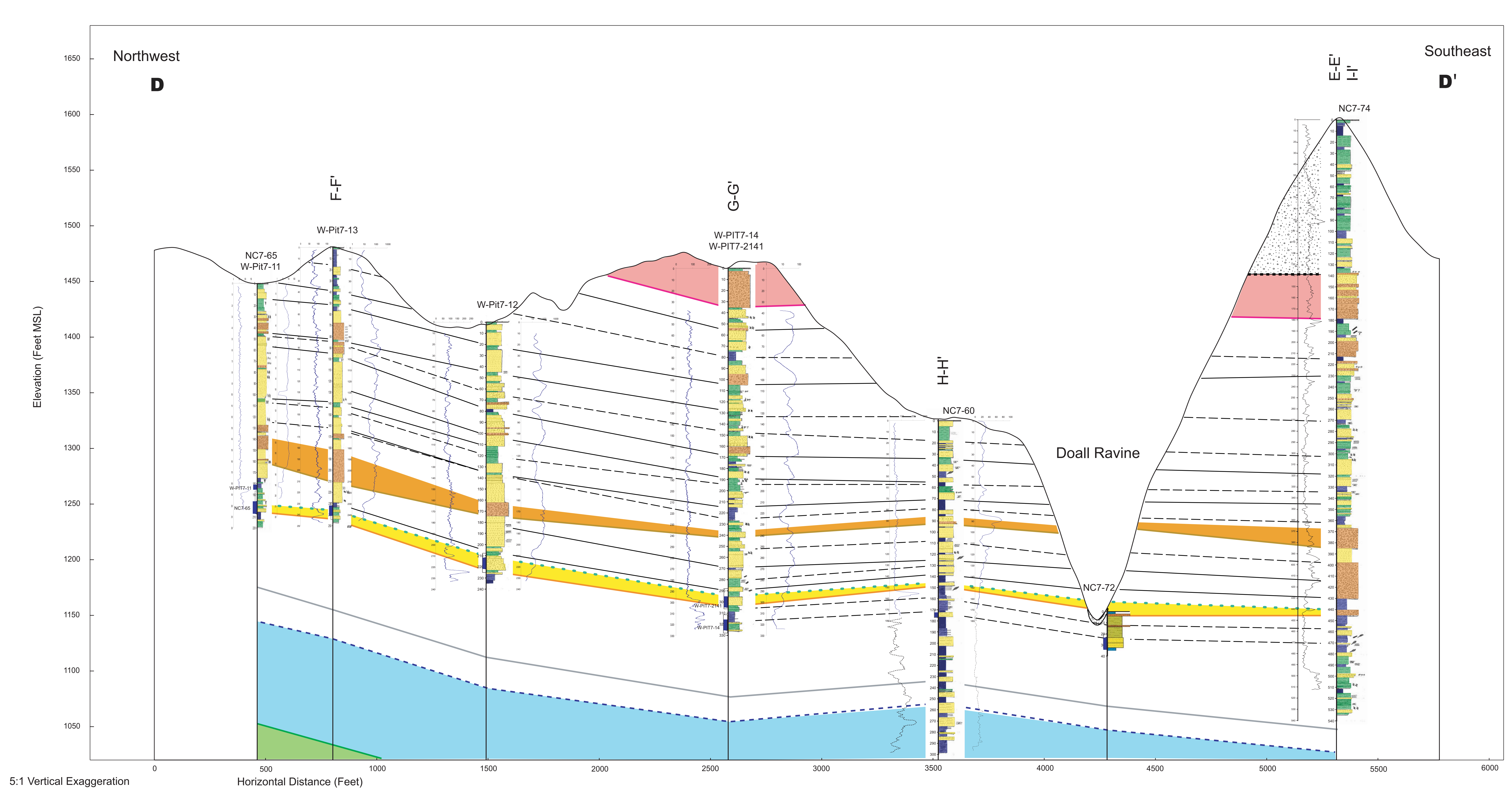

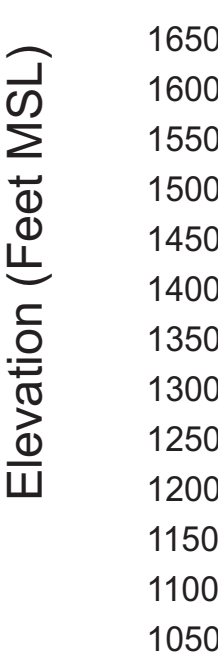
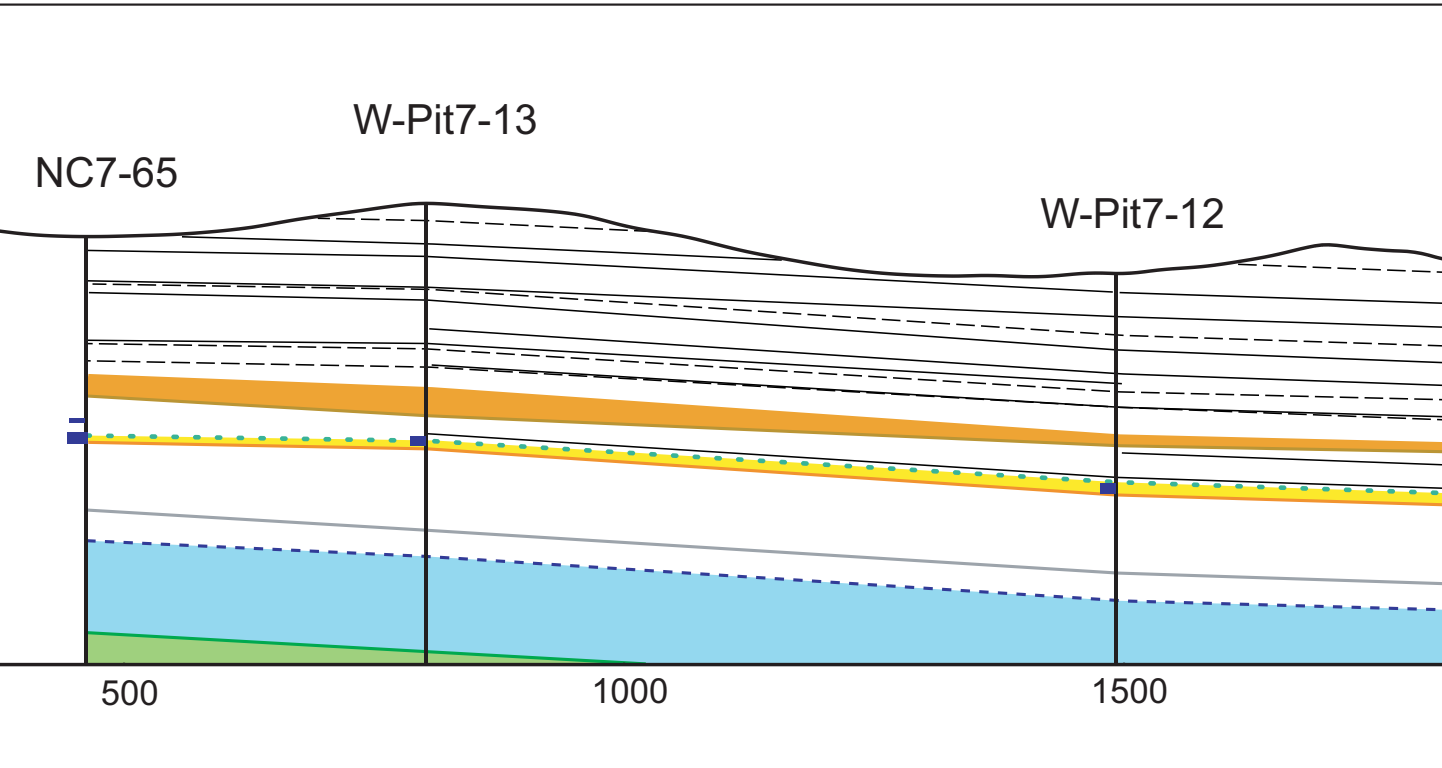

W-Pit7-14
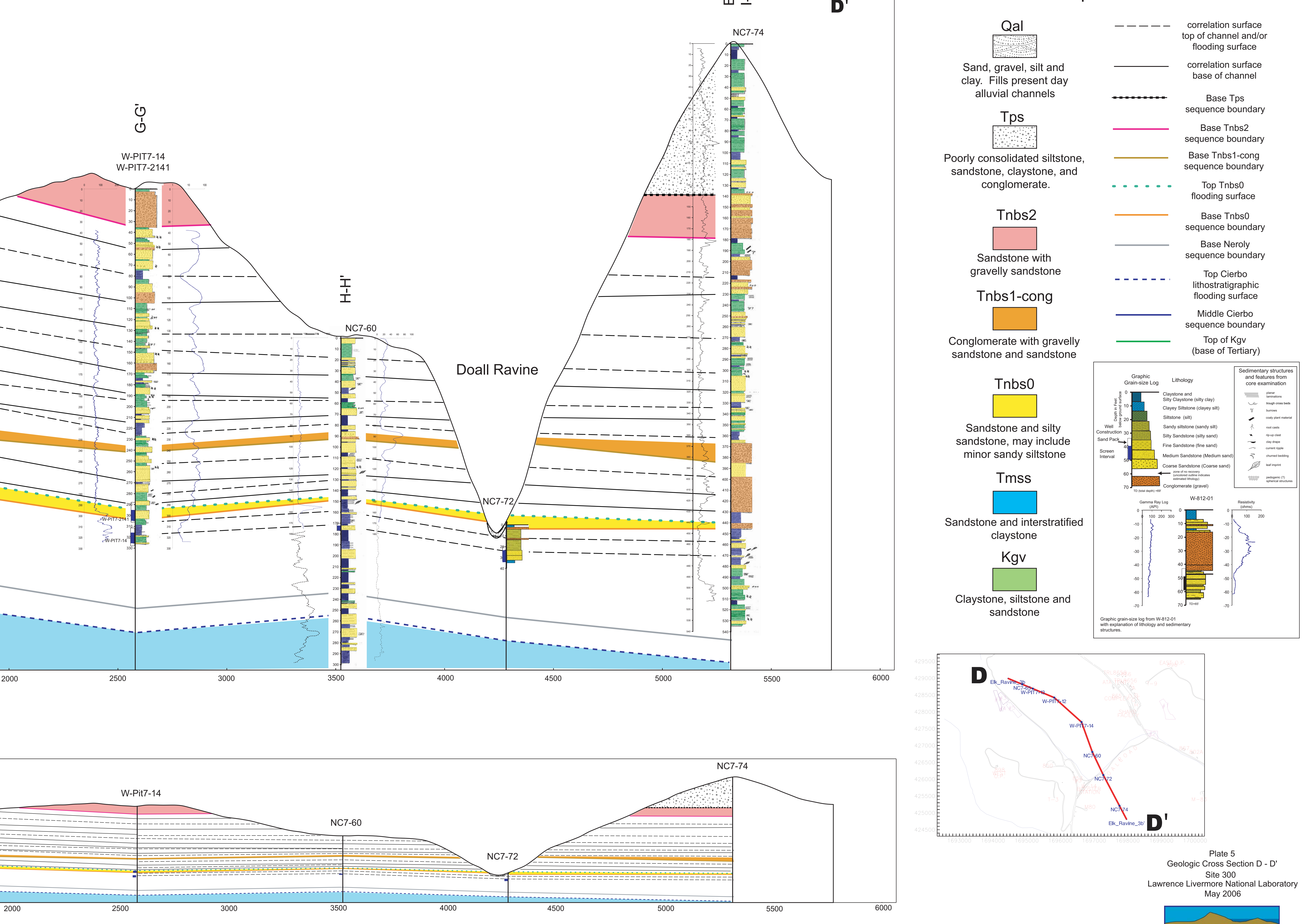

2500

3000

3500

4000

${ }^{4500}$

5000

Plate 5
Geologic Corss Section D - D'
Site 300

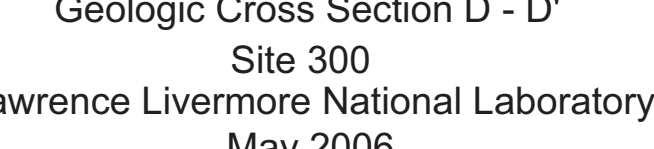

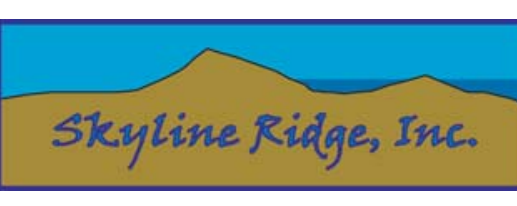




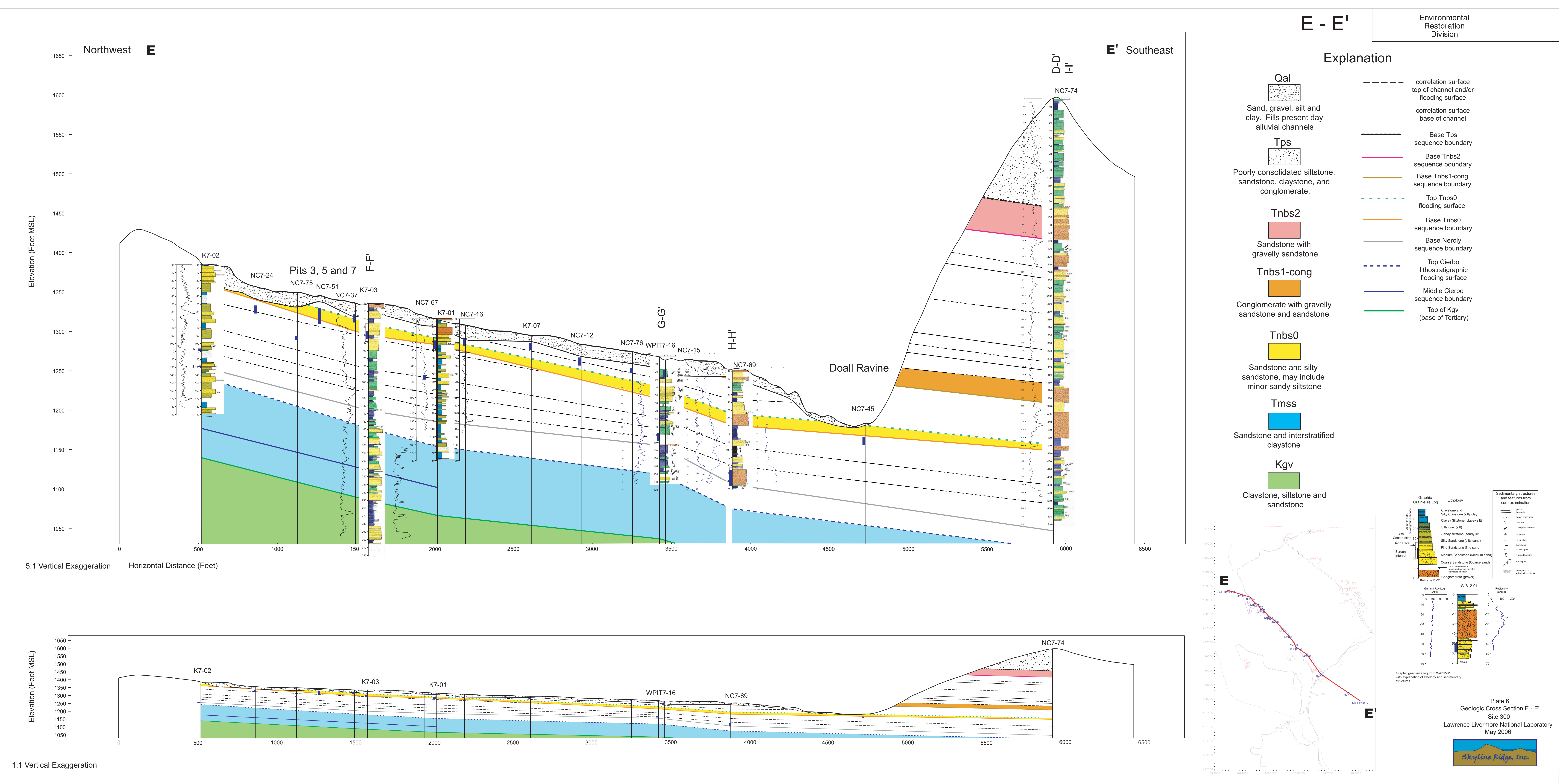




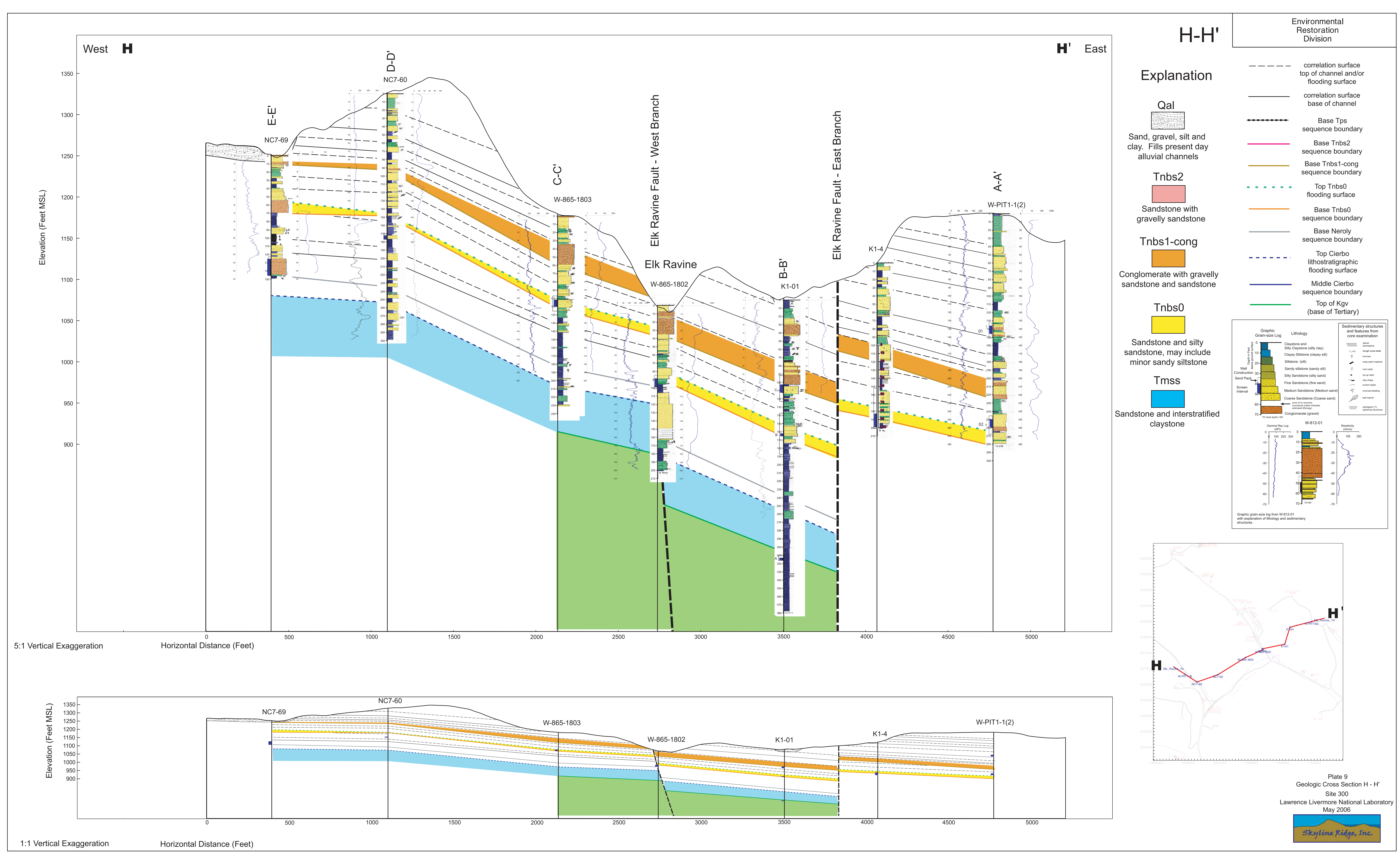





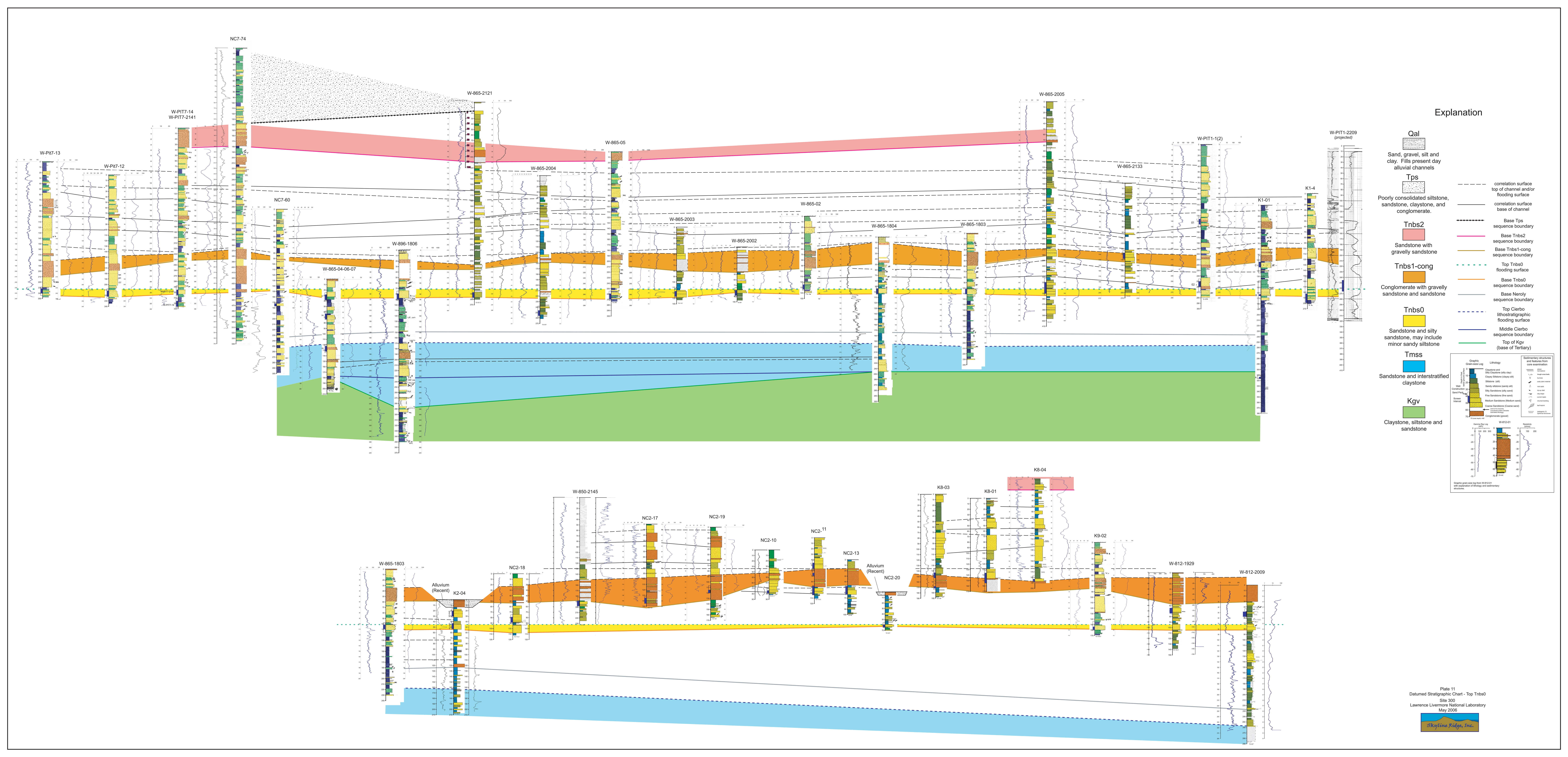




\section{Appendix A}

The following appendix contains the table of stratigraphic surface picks from each well/borehole used in this investigation. 


\begin{tabular}{|c|c|c|c|c|c|c|c|c|c|c|c|c|}
\hline LOC_ID & USGS_EAST & USGS_NORTH & scrntop_dep & scrnbot_dep & sandtop_dep & sandbot_dep & casing_dep & GRND_ELEV & T/Qal & depth & B/Qal & depth \\
\hline K1-01A (B, C) & 1699062.30 & 427774.28 & 312 & 315 & 310 & 315 & 312 & 1078.92 & $\mathrm{NA}$ & NA & 1065.9 & 13.0 \\
\hline K1-04 & 1699231.70 & 428315.51 & 183 & 200 & 152 & 201 & 201 & 1120.00 & $\mathrm{NA}$ & NA & $\mathrm{NA}$ & NA \\
\hline K2-04D (S) & 1698120.48 & 426931.65 & 43 & 53 & 40 & 54 & 53 & 1089.22 & 1089.2 & 0.0 & 1075.2 & 14.0 \\
\hline K7-01 & 1694982.00 & 427876.40 & 28 & 39 & 23.5 & 42 & 39 & 1316.72 & 1316.7 & 0.0 & 1305.8 & 10.9 \\
\hline K7-02A (B, C) & 1693942.29 & 428701.28 & 107 & 109 & 93 & 114 & 109 & 1384.71 & NA & $\mathrm{NA}$ & NA & $\mathrm{NA}$ \\
\hline K7-03 & 1694695.90 & 428204.20 & 35 & 45 & 26 & 58 & 45 & 1335.79 & 1335.8 & 0.0 & 1325.8 & 10.0 \\
\hline K8-01 & 1702057.60 & 426653.90 & 155 & 165 & 131.8 & 169.8 & 165 & 1098.44 & NA & $\mathrm{NA}$ & NA & NA \\
\hline K8-03A (B) & 1701980.60 & 426494.10 & 168 & 172 & 163.5 & 173 & 187.7 & 1096.59 & $\mathrm{NA}$ & $\mathrm{NA}$ & $\mathrm{NA}$ & NA \\
\hline |K8-04 & 1702633.60 & 426754.20 & 183 & 188 & 177 & 188.5 & 188 & 1129.84 & NA & NA & NA & $\mathrm{NA}$ \\
\hline K9-02 & 1700809.50 & 422973.20 & 153.5 & 158.5 & 147 & 158.5 & 158.5 & 1133.09 & $\mathrm{NA}$ & $\mathrm{NA}$ & $\mathrm{NA}$ & NA \\
\hline NC2-10 & 1700685.30 & 426952.20 & 74 & 79 & 69.5 & 80 & 79 & 1038.10 & 1038.1 & 0.0 & 1022.6 & 15.5 \\
\hline NC2-11D $(I, S)$ & 1700888.10 & 426116.80 & 88.25 & 103 & 87 & 103 & 103 & 1025.30 & 1025.3 & 0.0 & 1021.3 & 4.0 \\
\hline NC2-13 & 1700661.90 & 425879.80 & 48.4 & 63 & 47.5 & 64 & 63 & 1018.20 & 1018.2 & 0.0 & 999.8 & 18.4 \\
\hline NC2-17 & 1699382.40 & 426409.40 & 134.7 & 144.7 & 132.2 & 144.7 & 144.7 & 1086.52 & $\mathrm{NA}$ & NA & $\mathrm{NA}$ & $\mathrm{NA}$ \\
\hline NC2-18 & 1698304.50 & 426652.80 & 79.3 & 89.2 & 72.3 & 90.5 & 89.8 & 1128.29 & $\mathrm{NA}$ & NA & $\mathrm{NA}$ & $\mathrm{NA}$ \\
\hline |NC2-19 & 1699814.00 & 425609.20 & 114.7 & 119.6 & 107 & 119.8 & 119.7 & 1090.09 & NA & $\mathrm{NA}$ & NA & $\mathrm{NA}$ \\
\hline NC2-20 (21) & 1701299.30 & 424866.60 & 59.5 & 64.4 & 56 & 64.7 & 64.4 & 998.97 & 999.0 & 0.0 & 998.5 & 0.5 \\
\hline NC7-29 & 1696492.70 & 425127.70 & 41 & 56 & 30.5 & 57 & 56 & 1252.44 & 1252.4 & 0.0 & 1227.9 & 24.5 \\
\hline NC7-47 & 1695338.80 & 429407.70 & 54 & 64 & 46 & 65 & 64 & 1265.53 & NA & NA & $\mathrm{NA}$ & NA \\
\hline NC7-50 & 1695559.50 & 430584.00 & 90 & 95 & 83 & 95 & 95 & 1196.75 & NA & $\mathrm{NA}$ & $\mathrm{NA}$ & $\mathrm{NA}$ \\
\hline NC7-60 & 1696943.80 & 426808.40 & 172.4 & 177.5 & 170 & 177.5 & 177.5 & 1324.65 & NA & $\mathrm{NA}$ & $\mathrm{NA}$ & $\mathrm{NA}$ \\
\hline NC7-65 (W-Pit7-11) & 1694862.10 & 428818.10 & 196.25 & 206.5 & 187 & 207 & 200.5 & 1448.31 & $\mathrm{NA}$ & NA & $\mathrm{NA}$ & NA \\
\hline NC7-69 & 1696278.33 & 426574.26 & 126.1 & 146.1 & 123 & 146.5 & 146.5 & 1250.33 & 1250.3 & 0.0 & 1242.3 & 8.0 \\
\hline NC7-72 & 1697270.70 & 426123.00 & 23.1 & 33.1 & 20 & 33.5 & 33.1 & 1153.38 & 1153.4 & 0.0 & 1151.4 & 2.0 \\
\hline NC7-74 & 1697750.00 & 425210.00 & $\mathrm{NA}$ & $\mathrm{NA}$ & $\mathrm{NA}$ & $\mathrm{NA}$ & $\mathrm{NA}$ & 1595.00 & $\mathrm{NA}$ & $\mathrm{NA}$ & $\mathrm{NA}$ & NA \\
\hline W-812-04 & 1703522.06 & 422931.30 & 121 & 131 & 117 & 132 & 131.75 & 942.94 & $\mathrm{NA}$ & $\mathrm{NA}$ & $\mathrm{NA}$ & $\mathrm{NA}$ \\
\hline W-812-1922 & 1703697.10 & 422467.50 & 66 & 76 & 61 & 77 & 76.5 & 891.34 & 891.3 & 0.0 & 888.3 & 3.0 \\
\hline W-812-1929 & 1703061.62 & 423375.61 & 64 & 74 & 60 & 76.5 & 74.8 & 1010.57 & $\mathrm{NA}$ & $\mathrm{NA}$ & NA & $\mathrm{NA}$ \\
\hline W-812-2009 & 1703169.40 & 423070.34 & 48 & 58 & 43 & 61 & 287 & 1004.69 & 1004.7 & 0.0 & 1004.7 & 0.0 \\
\hline W-850-2145 & & & & & & & & 1209.02 & $\mathrm{NA}$ & $\mathrm{NA}$ & NA & $\mathrm{NA}$ \\
\hline W-851-07 & 1695644.08 & 423793.47 & 196.3 & 206.2 & 190 & 200 & 206.2 & 1268.78 & $\mathrm{NA}$ & $\mathrm{NA}$ & NA & $\mathrm{NA}$ \\
\hline W-865-01 & 16966004.30 & 428832.21 & 45 & 55 & 41.5 & 58 & 55.5 & 1184.87 & 1184.9 & 0.0 & 1166.9 & 18.0 \\
\hline W-865-02 & 1698189.37 & 428567.05 & 124 & 134 & 122 & 135.5 & 134.7 & 1110.40 & NA & NA & $\mathrm{NA}$ & $\mathrm{NA}$ \\
\hline W-865-03 & 1695990.59 & 429354.19 & 46 & 56 & 43 & 57 & 56.7 & 1233.98 & $\mathrm{NA}$ & $\mathrm{NA}$ & NA & NA \\
\hline |W-865-05 & 1698616.86 & 428819.65 & 260 & 270 & 255.5 & 272 & 270.9 & 1229.57 & NA & $\mathrm{NA}$ & NA & $\mathrm{NA}$ \\
\hline W-865-06 (04, 07) & 1696545.99 & 429746.27 & 122 & 132 & 119 & 134 & 132.5 & 1152.61 & $\mathrm{NA}$ & NA & $\mathrm{NA}$ & $\mathrm{NA}$ \\
\hline W-865-1802 & 1698374.67 & 427599.45 & 89 & 99 & 84.5 & 101.3 & 99.5 & 1067.05 & $\mathrm{NA}$ & NA & NA & NA \\
\hline W-865-1803 & 1697821.33 & 427353.07 & 101 & 11 & 97 & 115 & 111.8 & 1177.99 & $\mathrm{NA}$ & $\mathrm{NA}$ & $\mathrm{NA}$ & $\mathrm{NA}$ \\
\hline W-865-1804 & 1697201.86 & 428037.41 & 93 & 103 & 88.5 & 104.1 & 103.8 & 1210.11 & $\mathrm{NA}$ & $\mathrm{NA}$ & $\mathrm{NA}$ & $\mathrm{NA}$ \\
\hline W-896-1806 & 1698533.94 & 429998.65 & 80.00 & 90.00 & 75.00 & 92.00 & 90.8 & 1202.37 & $\mathrm{NA}$ & NA & $\mathrm{NA}$ & $\mathrm{NA}$ \\
\hline W-PIT1-02 (01) & 1699912.16 & 428494.39 & 250 & 260 & 245 & 268 & 261 & 1179.30 & $\mathrm{NA}$ & $\mathrm{NA}$ & $\mathrm{NA}$ & NA \\
\hline |W-PIT7-12 & 1695812.76 & 428422.03 & 212 & 222 & 208 & 225.5 & 222.5 & 1413.51 & NA & NA & NA & $\mathrm{NA}$ \\
\hline W-PIT7-13 & 1695176.38 & 428688.10 & 232 & 242 & 229 & 245 & 242.8 & 1480.54 & NA & $\mathrm{NA}$ & $\mathrm{NA}$ & NA \\
\hline W-PIT7-14 & 1696622.59 & 427696.08 & 316 & 326 & 312 & 328.5 & 326.8 & 1461.24 & $\mathrm{NA}$ & $\mathrm{NA}$ & $\mathrm{NA}$ & $\mathrm{NA}$ \\
\hline W-PIT7-15 & 1695689.00 & 429095.00 & 101 & 111 & 97 & 112 & 111.5 & 1292.82 & $\mathrm{NA}$ & $\mathrm{NA}$ & $\mathrm{NA}$ & $\mathrm{NA}$ \\
\hline W-PIT7-16 & 1695894.32 & 426825.36 & 98 & 108 & 94 & 110 & 108.8 & 1269.00 & 1269.0 & 0.0 & 1252.0 & 17.0 \\
\hline W-PIT7-1725 & 1693960.35 & 428104.70 & 98 & 118 & 93 & 120 & 118.42 & 1418.05 & $\mathrm{NA}$ & $\mathrm{NA}$ & $\mathrm{NA}$ & $\mathrm{NA}$ \\
\hline W-865-2002 & 1697843.33 & 428741.90 & 79 & 89 & 74 & 91 & 90 & 1093.78 & NA & $\mathrm{NA}$ & $\mathrm{NA}$ & $\mathrm{NA}$ \\
\hline W-865-2003 & 1698039.52 & 428886.80 & 117 & 127 & 112 & 129 & 128 & 1109.44 & NA & NA & NA & NA \\
\hline W-865-2004 & 1698587.82 & 429187.80 & 246 & 256 & 238 & 258 & 257 & 1093.78 & $\mathrm{NA}$ & NA & $\mathrm{NA}$ & NA \\
\hline W-865-2005 & 1699555.36 & 428990.64 & 330 & 350 & 322 & 353 & 351 & 1272.87 & 1272.9 & 0 & $\mathrm{NA}$ & $\mathrm{NA}$ \\
\hline W-865-2121 & 1699103.22 & 429502.81 & 347 & 357 & 342 & 359 & 358 & 1285 & NA & NA & NA & NA \\
\hline W-865-2133 & 1701000 & 430000 & 128 & 138 & 125 & 140 & 139 & 1040 & $\mathrm{NA}$ & $\mathrm{NA}$ & $\mathrm{NA}$ & NA \\
\hline
\end{tabular}




\begin{tabular}{|c|c|c|c|c|c|c|c|c|c|c|}
\hline LOC_ID & $\mathrm{B} / \mathrm{Tps}$ & depth & $\mathrm{B} / \mathrm{Tnbs} 2$ & depth & B/ Tnbs1-cong & depth & $\mathrm{T} / \mathrm{Tnbs} 0$ & depth & B / Tnbso & depth \\
\hline K1-01A (B, C) & $\mathrm{NA}$ & NA & $\mathrm{NA}$ & $\mathrm{NA}$ & 976.9 & 102.0 & 926.9 & 152.0 & 913.9 & 165.0 \\
\hline K1-04 & $\mathrm{NA}$ & $\mathrm{NA}$ & $\mathrm{NA}$ & $\mathrm{NA}$ & 1001.0 & 119.0 & 944.0 & 176.0 & 930.0 & 190.0 \\
\hline K2-04D (S) & $\mathrm{NA}$ & $\mathrm{NA}$ & $\mathrm{NA}$ & $\mathrm{NA}$ & $\mathrm{NA}$ & $\mathrm{NA}$ & 1050.2 & 39.0 & 1035.2 & 54.0 \\
\hline k7-01 & $\mathrm{NA}$ & $\mathrm{NA}$ & $\mathrm{NA}$ & $\mathrm{NA}$ & $\mathrm{NA}$ & $\mathrm{NA}$ & 1292.7 & 24.0 & 1283.7 & 33.0 \\
\hline K7-02A (B, C) & NA & $\mathrm{NA}$ & $\mathrm{NA}$ & $\mathrm{NA}$ & $N A$ & NA & $\mathrm{NA}$ & $\mathrm{NA}$ & 1361.7 & 23.0 \\
\hline K7-03 & $\mathrm{NA}$ & $\mathrm{NA}$ & $\mathrm{NA}$ & $\mathrm{NA}$ & $\mathrm{NA}$ & $\mathrm{NA}$ & 1311.8 & 24.0 & 1295.8 & 40.0 \\
\hline K8-01 & NA & $\mathrm{NA}$ & NA & $\mathrm{NA}$ & NA & NA & NA & NA & NA & NA \\
\hline K8-03A (B) & $\mathrm{NA}$ & $\mathrm{NA}$ & $\mathrm{NA}$ & $\mathrm{NA}$ & 926.6 & 170.0 & NA & NA & $\mathrm{NA}$ & $\mathrm{NA}$ \\
\hline K8-04 & $\mathrm{NA}$ & $\mathrm{NA}$ & 1109.8 & 20.0 & $\mathrm{NA}$ & $\mathrm{NA}$ & $\mathrm{NA}$ & $\mathrm{NA}$ & $\mathrm{NA}$ & NA \\
\hline K9-02 & $\mathrm{NA}$ & $\mathrm{NA}$ & $\mathrm{NA}$ & $\mathrm{NA}$ & 1049.1 & 84.0 & 981.1 & 152.0 & 973.1 & 160.0 \\
\hline NC2-10 & $N A$ & $\mathrm{NA}$ & $\mathrm{NA}$ & $\mathrm{NA}$ & 981.1 & 57.0 & $\mathrm{NA}$ & $\mathrm{NA}$ & $\mathrm{NA}$ & $\mathrm{NA}$ \\
\hline NC2-11D (I, S) & NA & NA & $\mathrm{NA}$ & NA & 935.3 & 90.0 & $\mathrm{NA}$ & $\mathrm{NA}$ & $\mathrm{NA}$ & NA \\
\hline NC2-13 & $\mathrm{NA}$ & $\mathrm{NA}$ & $\mathrm{NA}$ & $\mathrm{NA}$ & 972.2 & 46.0 & $\mathrm{NA}$ & $\mathrm{NA}$ & $\mathrm{NA}$ & $\mathrm{NA}$ \\
\hline NC2-17 & $\mathrm{NA}$ & $\mathrm{NA}$ & $\mathrm{NA}$ & $\mathrm{NA}$ & $\mathrm{NA}$ & $\mathrm{NA}$ & NA & NA & $\mathrm{NA}$ & NA \\
\hline \begin{tabular}{|l|} 
NC2-18 \\
\end{tabular} & $\mathrm{NA}$ & $\mathrm{NA}$ & $\mathrm{NA}$ & $\mathrm{NA}$ & 1075.3 & 53.0 & 1034.3 & 94.0 & 1020.3 & 108.0 \\
\hline NC2-19 & $\mathrm{NA}$ & $\mathrm{NA}$ & $\mathrm{NA}$ & $\mathrm{NA}$ & 957.1 & 133.0 & 930.1 & 160.0 & $\mathrm{NA}$ & NA \\
\hline NC2-20 (21) & $\mathrm{NA}$ & $\mathrm{NA}$ & $\mathrm{NA}$ & $\mathrm{NA}$ & $\mathrm{NA}$ & $\mathrm{NA}$ & 940.0 & 59.0 & 935.0 & 64.0 \\
\hline NC7-29 & $\mathrm{NA}$ & $\mathrm{NA}$ & $\mathrm{NA}$ & $\mathrm{NA}$ & $\mathrm{NA}$ & NA & 1210.4 & 42.0 & 1207.4 & 45.0 \\
\hline NC7-47 & NA & $\mathrm{NA}$ & $\mathrm{NA}$ & NA & $N A$ & NA & 1214.5 & 51.0 & 1204.5 & 61.0 \\
\hline NC7-50 & $\mathrm{NA}$ & $\mathrm{NA}$ & $\mathrm{NA}$ & $\mathrm{NA}$ & $\mathrm{NA}$ & $\mathrm{NA}$ & $\mathrm{NA}$ & $\mathrm{NA}$ & NA & NA \\
\hline NC7-60 & $\mathrm{NA}$ & $\mathrm{NA}$ & $\mathrm{NA}$ & $\mathrm{NA}$ & 1232.7 & 92.0 & 1179.7 & 145.0 & 1176.7 & 148.0 \\
\hline NC7-65 (W-Pit7-11) & NA & $\mathrm{NA}$ & $\mathrm{NA}$ & NA & 1289.3 & 159.0 & 1249.3 & 199.0 & 1243.3 & 205.0 \\
\hline NC7-69 & $\mathrm{NA}$ & $\mathrm{NA}$ & $\mathrm{NA}$ & $\mathrm{NA}$ & 1239.3 & 11.0 & 1195.3 & 55.0 & 1181.3 & 69.0 \\
\hline NC7-72 & NA & $\mathrm{NA}$ & $\mathrm{NA}$ & $\mathrm{NA}$ & $\mathrm{NA}$ & NA & $\mathrm{NA}$ & $\mathrm{NA}$ & 1149.4 & 4.0 \\
\hline NC7-74 & 1456.0 & 139.0 & 1417.0 & 178.0 & 1210.0 & 385.0 & 1155.0 & 440.0 & 1150.0 & 445.0 \\
\hline |W-812-04 & NA & NA & $N A$ & $\mathrm{NA}$ & $N A$ & $\mathrm{NA}$ & NA & $\mathrm{NA}$ & $\mathrm{NA}$ & NA \\
\hline W-812-1922 & $\mathrm{NA}$ & $\mathrm{NA}$ & $\mathrm{NA}$ & $\mathrm{NA}$ & $\mathrm{NA}$ & $\mathrm{NA}$ & $\mathrm{NA}$ & $\mathrm{NA}$ & $\mathrm{NA}$ & $\mathrm{NA}$ \\
\hline W-812-1929 & $\mathrm{NA}$ & NA & NA & NA & 953.6 & 57.0 & 916.6 & 94.0 & 899.6 & 111.0 \\
\hline W-812-2009 & $\mathrm{NA}$ & $\mathrm{NA}$ & $\mathrm{NA}$ & $\mathrm{NA}$ & 974.7 & 30.0 & 934.7 & 70.0 & 922.7 & 82.0 \\
\hline W-850-2145 & $\mathrm{NA}$ & $\mathrm{NA}$ & $\mathrm{NA}$ & $\mathrm{NA}$ & 1021.0 & 188.0 & $\mathrm{NA}$ & NA & $\mathrm{NA}$ & $\mathrm{NA}$ \\
\hline |W-851-07 & $N A$ & NA & $\mathrm{NA}$ & $\mathrm{NA}$ & $\mathrm{NA}$ & $N A$ & NA & $\mathrm{NA}$ & $\mathrm{NA}$ & NA \\
\hline W-865-01 & NA & $\mathrm{NA}$ & $\mathrm{NA}$ & $\mathrm{NA}$ & $\mathrm{NA}$ & NA & 1156.9 & 28.0 & 1149.9 & 35.0 \\
\hline W-865-02 & $\mathrm{NA}$ & $\mathrm{NA}$ & $\mathrm{NA}$ & $\mathrm{NA}$ & 1015.4 & 94.0 & 978.4 & 132.0 & NA & NA \\
\hline W-865-03 & $\mathrm{NA}$ & $\mathrm{NA}$ & $\mathrm{NA}$ & $\mathrm{NA}$ & 1219.0 & 15.0 & 1190.0 & 44.0 & 1178.0 & 56.0 \\
\hline W-865-05 & $\mathrm{NA}$ & $\mathrm{NA}$ & 1213.6 & 16.0 & 1024.6 & 205.0 & 976.6 & 253.0 & 960.6 & 269.0 \\
\hline W-865-06 (04, 07) & $\mathrm{NA}$ & $\mathrm{NA}$ & $\mathrm{NA}$ & $\mathrm{NA}$ & 1149.6 & 3.0 & 1132.6 & 20.0 & 1120.6 & 32.0 \\
\hline W-865-1802 & $\mathrm{NA}$ & $\mathrm{NA}$ & NA & NA & 1033.1 & 34.0 & 991.1 & 76.0 & 978.1 & 89.0 \\
\hline |W-865-1803 & NA & $\mathrm{NA}$ & $\mathrm{NA}$ & $N A$ & 1119.0 & 59.0 & 1076.0 & 102.0 & 1067.0 & 111.0 \\
\hline W-865-1804 & NA & $\mathrm{NA}$ & $N A$ & NA & 1163.1 & 47.0 & 1116.1 & 94.0 & 1107.1 & 103.0 \\
\hline W-896-1806 & $\mathrm{NA}$ & $\mathrm{NA}$ & $\mathrm{NA}$ & $\mathrm{NA}$ & 1162.4 & 40.0 & 1131.4 & 71.0 & 1115.37 & 87.0 \\
\hline W-PIT1-02 (01) & $\mathrm{NA}$ & $\mathrm{NA}$ & NA & $\mathrm{NA}$ & 954.3 & 225.0 & 915.3 & 264.0 & $\mathrm{NA}$ & $\mathrm{NA}$ \\
\hline W-PIT7-12 & NA & $\mathrm{NA}$ & NA & $\mathrm{NA}$ & 1239.5 & 174.0 & 1203.5 & 210.0 & 1190.5 & 223.0 \\
\hline |W-PIT7-13 & NA & $\mathrm{NA}$ & $\mathrm{NA}$ & NA & 1269.5 & 211.0 & 1244.5 & 236.0 & 1236.5 & 244.0 \\
\hline W-PIT7-14 & $\mathrm{NA}$ & $\mathrm{NA}$ & 1426.2 & 35.0 & 1219.2 & 242.0 & 1166.2 & 295.0 & 1157.2 & 304.0 \\
\hline W-PIT7-15 & NA & $\mathrm{NA}$ & $\mathrm{NA}$ & NA & 1234.8 & 58.0 & 1190.8 & 102.0 & 1179.8 & 113.0 \\
\hline W-PIT7-16 & $\mathrm{NA}$ & $\mathrm{NA}$ & NA & $\mathrm{NA}$ & $\mathrm{NA}$ & $\mathrm{NA}$ & 1230.0 & 39.0 & 1214.0 & 55.0 \\
\hline W-PIT7-1725 & $\mathrm{NA}$ & NA & NA & $\mathrm{NA}$ & $\mathrm{NA}$ & $\mathrm{NA}$ & 1409.1 & 9.0 & 1392.1 & 26.0 \\
\hline W-865-2002 & NA & NA & $\mathrm{NA}$ & NA & 1046.8 & 47.0 & 1014.8 & 79.0 & 1009.8 & 84.0 \\
\hline |W-865-2003 & NA & $\mathrm{NA}$ & $\mathrm{NA}$ & $\mathrm{NA}$ & 1029.4 & 80.0 & 993.4 & 116.0 & 981.4 & 128.0 \\
\hline W-865-2004 & NA & $\mathrm{NA}$ & $\mathrm{NA}$ & NA & 935.8 & 158.0 & 884.8 & 209.0 & 868.8 & 225.0 \\
\hline W-865-2005 & NA & $\mathrm{NA}$ & 1198.9 & 74.0 & 955.9 & 317.0 & 931.9 & 341.0 & 918.9 & 354.0 \\
\hline |W-865-2121 & 1269.0 & 16.0 & 1174.0 & 111.0 & 978.0 & 307.0 & 941.0 & 344.0 & 929.0 & 356.0 \\
\hline W-865-2133 & $\mathrm{NA}$ & $\mathrm{NA}$ & $\mathrm{NA}$ & $\mathrm{NA}$ & 894.0 & 146.0 & $\mathrm{NA}$ & $\mathrm{NA}$ & $\mathrm{NA}$ & $N A$ \\
\hline
\end{tabular}




\begin{tabular}{|c|c|c|c|c|c|c|c|c|c|c|c|c|c|c|}
\hline LOC_ID & T/ Tnsco & depth & $\mathrm{B} / \mathrm{Tnsc0}$ & depth & T/Tmss & depth & Mid/ Tmss & depth & B/ Tmss & depth & $\mathrm{T} / \mathrm{Kgv}$ & depth & TD Elev & toff thgs \\
\hline K1-01A (B, C) & 913.9 & 165.0 & 841.9 & 237.0 & 822.9 & 256.0 & $\mathrm{NA}$ & NP & 773.9 & 305.0 & 773.9 & 305.0 & $\begin{array}{ll}701.4 \\
\end{array}$ & 377.5 \\
\hline K1-04 & 930.0 & 190.0 & $\mathrm{NA}$ & $\mathrm{NA}$ & $\mathrm{NA}$ & $\mathrm{NA}$ & $\mathrm{NA}$ & NA & $\mathrm{NA}$ & NA & NA & $\mathrm{NA}$ & 919.0 & 201 \\
\hline K2-04D (S) & 1035.2 & 54.0 & 966.2 & 123.0 & 926.2 & 163.0 & $\mathrm{NA}$ & NA & $\mathrm{NA}$ & NA & NA & $\mathrm{NA}$ & 1034.4 & 54.8 \\
\hline K7-01 & 1283.7 & 33.0 & 1186.7 & 130.0 & 1154.7 & 162.0 & $\mathrm{NA}$ & NA & NA & NA & NA & NA & 1139.2 & 177.5 \\
\hline K7-02A (B, C) & 1361.7 & 23.0 & 1255.7 & 129.0 & 1242.7 & 142.0 & $\mathrm{NA}$ & NA & $\mathrm{NA}$ & NA & NA & $\mathrm{NA}$ & 1196.2 & 188.5 \\
\hline K7-03 & 1295.8 & 40.0 & 1199.8 & 136.0 & 1176.8 & 159.0 & 1123.8 & 212.0 & 1085.8 & 250.0 & 1085.8 & 250.0 & 1031.8 & 304 \\
\hline K8-01 & $\mathrm{NA}$ & NA & NA & NA & NA & $\mathrm{NA}$ & $\mathrm{NA}$ & NA & $\mathrm{NA}$ & NA & NA & $\mathrm{NA}$ & 928.6 & 169.8 \\
\hline K8-03A (B) & $\mathrm{NA}$ & NA & $\mathrm{NA}$ & $\mathrm{NA}$ & $\mathrm{NA}$ & $\mathrm{NA}$ & $\mathrm{NA}$ & NA & $\mathrm{NA}$ & $\mathrm{NA}$ & NA & $\mathrm{NA}$ & 923.6 & 173 \\
\hline K8-04 & NA & NA & NA & NA & NA & NA & NA & $\mathrm{NA}$ & NA & NA & NA & NA & 941.3 & 188.5 \\
\hline K9-02 & 973.1 & 160.0 & $\mathrm{NA}$ & $\mathrm{NA}$ & $\mathrm{NA}$ & $\mathrm{NA}$ & $\mathrm{NA}$ & NA & $\mathrm{NA}$ & NA & NA & $\mathrm{NA}$ & $\mathrm{NA}$ & $\mathrm{NA}$ \\
\hline NC2-10 & NA & NA & NA & NA & NA & NA & NA & $N A$ & NA & NA & NA & NA & 956.6 & 81.5 \\
\hline NC2-11D (I, S) & NA & $\mathrm{NA}$ & NA & NA & NA & NA & NA & $\mathrm{NA}$ & NA & NA & $N A$ & NA & 914.8 & 110.5 \\
\hline NC2-13 & $\mathrm{NA}$ & $\mathrm{NA}$ & $\mathrm{NA}$ & $\mathrm{NA}$ & $\mathrm{NA}$ & $\mathrm{NA}$ & NA & NA & $\mathrm{NA}$ & NA & NA & $\mathrm{NA}$ & 918.9 & 99.3 \\
\hline NC2-17 & NA & $\mathrm{NA}$ & NA & NA & NA & NA & NA & $\mathrm{NA}$ & NA & NA & NA & NA & 937.5 & 149 \\
\hline NC2-18 & 1020.3 & 108.0 & $\mathrm{NA}$ & $\mathrm{NA}$ & $\mathrm{NA}$ & $\mathrm{NA}$ & $\mathrm{NA}$ & NA & $\mathrm{NA}$ & NA & NA & $\mathrm{NA}$ & 1016.1 & 112.2 \\
\hline NC2-19 & NA & $\mathrm{NA}$ & $\mathrm{NA}$ & NA & $\mathrm{NA}$ & $\mathrm{NA}$ & NA & NA & $\mathrm{NA}$ & $\mathrm{NA}$ & NA & $\mathrm{NA}$ & 925.1 & 165 \\
\hline NC2-20 (21) & 933.0 & 66.0 & NA & $\mathrm{NA}$ & NA & $\mathrm{NA}$ & NA & NA & NA & NA & $\mathrm{NA}$ & $\mathrm{NA}$ & 929.0 & 70 \\
\hline NC7-29 & $\begin{array}{ll}1207.4 \\
\end{array}$ & 45.0 & $\begin{array}{ll}1207.4 \\
\end{array}$ & 45.0 & $\mathrm{NA}$ & $\mathrm{NA}$ & $\mathrm{NA}$ & $\mathrm{NA}$ & $\mathrm{NA}$ & $\mathrm{NA}$ & NA & $\mathrm{NA}$ & 1193.4 & 59 \\
\hline NC7-47 & 1204.5 & 61.0 & NA & NA & $\mathrm{NA}$ & $\mathrm{NA}$ & NA & NA & $\mathrm{NA}$ & NA & NA & NA & 1195.5 & 70 \\
\hline NC7-50 & 1196.8 & 0.0 & 1190.8 & 6.0 & 1175.8 & 21.0 & $\mathrm{NA}$ & NA & 1090.3 & 106.5 & 1090.3 & 106.5 & 994.8 & 202 \\
\hline NC7-60 & 1176.7 & 148.0 & 1090.7 & 234.0 & 1070.7 & 254.0 & NA & $\mathrm{NA}$ & NA & NA & NA & NA & 1025.3 & 299.4 \\
\hline NC7-65 (W-Pit7-11) & 1243.3 & 205.0 & $\mathrm{NA}$ & $\mathrm{NA}$ & $\mathrm{NA}$ & $\mathrm{NA}$ & $\mathrm{NA}$ & NA & $\mathrm{NA}$ & $\mathrm{NA}$ & $\mathrm{NA}$ & $\mathrm{NA}$ & 1228.5 & 219.8 \\
\hline NC7-69 & 1181.3 & 69.0 & 144.0 & $\mathrm{NA}$ & $\mathrm{NA}$ & $\mathrm{NA}$ & $\mathrm{NA}$ & NA & NA & NA & NA & $\mathrm{NA}$ & 1100.6 & 149.7 \\
\hline NC7-72 & 1149.4 & 4.0 & NA & NA & NA & NA & $\mathrm{NA}$ & NA & NA & NA & NA & NA & 1118.7 & 34.7 \\
\hline NC7-74 & 1150.0 & 445.0 & $\mathrm{NA}$ & NA & NA & NA & NA & NA & NA & NA & NA & NA & 1060.0 & 535 \\
\hline W-812-04 & $\mathrm{NA}$ & $\mathrm{NA}$ & 839.9 & 103.0 & 821.9 & 121.0 & NA & NA & $\mathrm{NA}$ & & NA & $\mathrm{NA}$ & $\mathrm{NA}$ & NA \\
\hline W-812-1922 & 891.3 & 0.00 & 844.3 & 47.0 & 824.3 & 67.0 & $\mathrm{NA}$ & NA & $\mathrm{NA}$ & $\mathrm{NA}$ & NA & $\mathrm{NA}$ & 800.8 & 90.5 \\
\hline W-812-1929 & 899.6 & 111.0 & NA & NA & $\mathrm{NA}$ & $\mathrm{NA}$ & $\mathrm{NA}$ & NA & $\mathrm{NA}$ & NA & NA & $\mathrm{NA}$ & 872.3 & 138.3 \\
\hline W-812-2009 & 922.7 & 82.0 & 777.7 & 227.0 & 736.7 & 268.0 & $\mathrm{NA}$ & NA & $\mathrm{NA}$ & $\mathrm{NA}$ & NA & $\mathrm{NA}$ & 717.7 & 287 \\
\hline W-850-2145 & NA & NA & $N A$ & NA & 1089.0 & 120.0 & NA & NA & $\mathrm{NA}$ & NA & NA & NA & NA & NA \\
\hline W-851-07 & $\mathrm{NA}$ & NA & 1190.8 & 78.0 & 1177.8 & 91.0 & 1088.8 & 180.0 & $\mathrm{NA}$ & NA & NA & $\mathrm{NA}$ & 1053.8 & 215 \\
\hline W-865-01 & 1149.9 & 35.0 & 1082.9 & 102.0 & 1064.9 & 120.0 & NA & NA & $\mathrm{NA}$ & NA & NA & NA & 1034.9 & 150 \\
\hline W-865-02 & NA & NA & NA & $\mathrm{NA}$ & NA & $\mathrm{NA}$ & $\mathrm{NA}$ & NA & $\mathrm{NA}$ & NA & NA & $\mathrm{NA}$ & 970.4 & 140 \\
\hline W-865-03 & 1178.0 & 56.0 & $\mathrm{NA}$ & $\mathrm{NA}$ & $\mathrm{NA}$ & $\mathrm{NA}$ & $\mathrm{NA}$ & NA & NA & NA & NA & $\mathrm{NA}$ & 1168.0 & 66 \\
\hline W-865-05 & 960.6 & 269.0 & NA & NA & NA & NA & NA & NA & $\mathrm{NA}$ & NA & NA & $\mathrm{NA}$ & 955.6 & 274 \\
\hline W-865-06 $(04,07)$ & 1120.6 & 32.0 & 1051.6 & 101.0 & 1033.6 & 119.0 & 991.6 & 161.0 & 992.6 & 160.0 & 976.6 & 176.0 & 950.6 & 202 \\
\hline W-865-1802 & 978.1 & 89.0 & 956.1 & 111.0 & 947.1 & 120.0 & NA & $N P$ & 887.1 & 180.0 & 887.1 & 180.0 & 866.6 & 200.5 \\
\hline W-865-1803 & 1067.0 & 111.0 & 996.0 & 182.0 & 971.0 & 207.0 & $\mathrm{NA}$ & NA & NA & NA & NA & $\mathrm{NA}$ & 947.0 & 231 \\
\hline W-865-1804 & 1107.1 & 103.0 & 1035.1 & 175.0 & 1014.1 & 196.0 & 1210.1 & & 965.1 & 245.0 & 965.1 & 245.0 & 931.1 & 279 \\
\hline W-896-1806 & 1115.4 & 87.0 & 1053.37 & 149.0 & 1032.4 & 170.0 & 972.4 & 230.0 & 913.37 & 289.0 & 913.4 & 289.0 & 850.4 & 352 \\
\hline W-PIT1-02 (01) & $\mathrm{NA}$ & $\mathrm{NA}$ & $\mathrm{NA}$ & $\mathrm{NA}$ & $\mathrm{NA}$ & $\mathrm{NA}$ & $\mathrm{NA}$ & NA & $\mathrm{NA}$ & $\mathrm{NA}$ & NA & NA & 901.3 & 278 \\
\hline W-PIT7-12 & 1190.5 & 223.0 & NA & NA & NA & $\mathrm{NA}$ & NA & NA & $\mathrm{NA}$ & NA & $\mathrm{NA}$ & NA & 1178.5 & 235 \\
\hline W-PIT7-13 & 1236.5 & 244.0 & NA & $\mathrm{NA}$ & NA & $\mathrm{NA}$ & $\mathrm{NA}$ & NA & $\mathrm{NA}$ & NA & NA & $\mathrm{NA}$ & 1232.5 & 248 \\
\hline W-PIT7-14 & 1157.2 & 304.0 & $\mathrm{NA}$ & $\mathrm{NA}$ & $\mathrm{NA}$ & $\mathrm{NA}$ & $\mathrm{NA}$ & NA & $\mathrm{NA}$ & $\mathrm{NA}$ & NA & $\mathrm{NA}$ & 1132.7 & 328.5 \\
\hline W-PIT7-15 & 1179.8 & 113.0 & $\mathrm{NA}$ & $\mathrm{NA}$ & $\mathrm{NA}$ & $\mathrm{NA}$ & $\mathrm{NA}$ & NA & $\mathrm{NA}$ & $\mathrm{NA}$ & NA & $\mathrm{NA}$ & 1167.8 & 125 \\
\hline W-PIT7-16 & 1214.0 & 55.0 & 1155.0 & 114.0 & 1120.0 & 149.0 & $\mathrm{NA}$ & NA & $\mathrm{NA}$ & NA & NA & $\mathrm{NA}$ & 1105.0 & 164 \\
\hline W-PIT7-1725 & 1392.1 & 26.0 & 1327.1 & 91.0 & 1309.1 & 109.0 & NA & NA & NA & $\mathrm{NA}$ & NA & $\mathrm{NA}$ & 1273.1 & 145 \\
\hline W-865-2002 & 1009.8 & 84.0 & $\mathrm{NA}$ & $\mathrm{NA}$ & $\mathrm{NA}$ & NA & $\mathrm{NA}$ & NA & $\mathrm{NA}$ & NA & NA & $\mathrm{NA}$ & 995.8 & 98 \\
\hline W-865-2003 & 981.4 & 128.0 & $\mathrm{NA}$ & NA & NA & $N A$ & NA & $N A$ & NA & NA & NA & $\mathrm{NA}$ & 976.4 & 133 \\
\hline W-865-2004 & 868.8 & 225.0 & $\mathrm{NA}$ & $\mathrm{NA}$ & $\mathrm{NA}$ & $\mathrm{NA}$ & $\mathrm{NA}$ & NA & $\mathrm{NA}$ & NA & NA & $\mathrm{NA}$ & 832.8 & 261 \\
\hline W-865-2005 & 918.9 & 354.0 & $\mathrm{NA}$ & $\mathrm{NA}$ & $\mathrm{NA}$ & $\mathrm{NA}$ & $\mathrm{NA}$ & NA & $\mathrm{NA}$ & $\mathrm{NA}$ & $\mathrm{NA}$ & $\mathrm{NA}$ & 871.9 & 401 \\
\hline W-865-2121 & 929.0 & 356.0 & NA & NA & NA & $\mathrm{NA}$ & $\mathrm{NA}$ & NA & NA & NA & NA & NA & 923.5 & 361.5 \\
\hline W-865-2133 & NA & $\mathrm{NA}$ & $\mathrm{NA}$ & $\mathrm{NA}$ & NA & $\mathrm{NA}$ & NA & NA & NA & NA & NA & NA & 839 & 201 \\
\hline
\end{tabular}

